International Journal of Earth Sciences

June 2009, Volume 98, Number 4, Pages 769-789

http://dx.doi.org/10.1007/s00531-008-0373-5

(c) 2009 Springer. Part of Springer Science+Business

Media

The original publication is available at http://www.springerlink.com
Archimer, archive institutionnelle de l'Ifremer http://www.ifremer.fr/docelec/

\title{
Quantifying the role of sandy-silty sediments in generating slope failures during earthquakes: example from the Algerian margin
}

\author{
Gabriela Dan ${ }^{1,2,5,{ }^{*}}$, Nabil Sultan ${ }^{1}$, Bruno Savoye ${ }^{1}$, Jacques Deverchere ${ }^{2,3}$ and Karim Yelles ${ }^{4}$ \\ ${ }^{1}$ IFREMER, Géosciences Marines, Laboratoire Environnements Sédimentaires, Plouzané, France \\ ${ }^{2}$ Université de Brest, CNRS, UMR 6538 Domaines Océaniques, Institut Universitaire Européen de la Mer, Place \\ Copernic, 29280 Plouzané, France \\ ${ }^{3}$ Université Européenne de Bretagne, Brest, France \\ ${ }^{4}$ CRAAG, Centre de Recherche en Astronomie, Astrophysique et Géophysique, Bouzaréah, Algiers, Algeria \\ ${ }^{5}$ Present address: FUGRO France S.A.S, 92752 Nanterre, France \\ *: Corresponding author : G. Dan, email address : G.Dan@fugro.com
}

\begin{abstract}
:
The Algerian margin is a seismically active region, where during the last century, several large magnitude earthquakes took place. This study combines geotechnical and sedimentological data with numerical modelling to quantitatively assess the present-day slope stability of the Algerian margin. Geotechnical laboratory tests, such as cyclic triaxial tests, oedometric tests and vane shear tests were carried out on sediment cores collected on the study area. The liquefaction potential of a sediment column located about $30 \mathrm{~km}$ from the Boumerdès earthquake epicentre of 21st May 2003 was evaluated theoretically for an earthquake of $M \quad w=6.8$. We show that thin sand and silt beds such as those described on recovered sediment cores are the main cause of sediment deformation and liquefaction during earthquakes. Numerical calculations showed that the slope failure may occur during an earthquake characterised by a PGA in excess of $0.1 \mathrm{~g}$, and also that, under a PGA of $0.2 \mathrm{~g}$ liquefaction could be triggered in shallow silty-sandy deposits. Moreover, comparison of the predicted slope failure with failure geometries inferred from seafloor morphology showed that earthquakes and subsequent mass movements could explain the present-day morphology of the study area.
\end{abstract}

Keywords: Algerian margin - Slope stability - Potential of liquefaction - Earthquakes 


\section{Introduction}

Submarine landslides, such as those triggered by earthquakes, can generate tsunami, loss of human lives and affect the coastal and seriously damage coastal and offshore infrastructures. Recent studies on the likely source area of the famous 1755 Lisbon tsunami, which followed a magnitude 8.5 earthquake and caused about 60000 casualties (Baptista et al. 1998; see also Canals et al. 2004 and references therein), have identified a potential tsunamigenic fault source and associated mass movements (Gracia et al. 2003). During the 1929 Great Banks earthquake and associated landslides initial slope failure occurred near the earthquake epicentre and were followed by a catastrophic tsunami. The slope failure, transformed into a debris flow, generated a turbidity current that cut off submarine telegraph cables (Heezen and Ewing 1952; Piper et al. 1985; Piper et al. 1999). A more recent example of a tsunami triggered by submarine landsliding is the one that impacted the Nice international airport. On $16^{\text {th }}$ of October 1979 , a part of the Nice airport, meant to be a harbour, collapsed into the sea. The harbour collapse was accompanied by a tsunami wave by a $2-3$ meters height tsunami wave (Gennesseaux et al. 1980). This catastrophic event caused the lost of human lives and important material damages.

During the last century, northern Algerian towns and villages have been affected by several destructive earthquakes. The last one, of $6.8 \mathrm{M}_{\mathrm{w}}$, occurred on the $21^{\text {st }}$ of May 2003 near the town of Boumerdès, Algiers region causing more than 2300 deaths and injuring around 10000 people. Besides casualties, the earthquake produced important damages onshore and offshore (cable breaks). The identification of active faults and the source of the earthquake in the Algiers 
region were accomplished by different authors (Bounif et al. 2004; Meghraoui et al. 2004; Déverchère et al. 2005; Semmane et al. 2005).

The phenomenon of liquefaction may appear during co-seismic motion generating deformations and leading to slope failure. During the last four decades and especially after the two 1964 earthquakes that occurred in Alaska (Good Friday, $M_{w}=9.2$ ) and Japan (Niigata, $M_{w}=7.5$ ), special attention was devoted to the experimental and theoretical study of the liquefaction phenomena onland. Work on sediment liquefaction was described in detail in numerous state-of-the-art papers, such as those by Yoshimi et al. (1977), Seed (1979), Finn (1981), Ishihara (1993) and Robertson and Fear (1995). Liquefaction is defined as a transformation of a granular sediment from a solid to a liquefied state as a consequence of increased pore pressure and reduced effective stress (Marcuson III 1978; Youd et al. 2001). In order to assess the liquefaction potential, several questions must be addressed (Kramer 1996): Is the sediment susceptible to liquefaction? If the sediment is susceptible, will liquefaction occur? If liquefaction is triggered, what damage will generate? Generally, the liquefaction susceptibility depends on the geological setting and the characteristics of the sediment (grain-size, presence or absence of clay fraction). For instance, only sandy and silty deposits are susceptible to liquefaction during an earthquake (Ishihara 1984). However, the fact that the sediment may be susceptible to liquefaction does not mean that liquefaction will necessary occur (Kramer 1996).

Recently, the response of submarine slopes to seismic loading was studied numerically by Biscontin and Pestana (2006). A series of numerical simulations were conducted using the AMPLE2000 software by Pestana and Nadim (2000) in order to investigate the influence of slope inclination, soil thickness and ground motion parameters. Biscontin and Pestana (2006) results show that even for slope 
angles lower than $5^{\circ}$, the slope inclination remains the key parameter in terms of accumulation of strain and amount of permanent displacement. Regarding sediment accumulations, it appears that shallow layers can accumulate larger strains and higher pore pressure ratios than deeper layers, which are able to dissipate the earthquake energy at the end of the earthquake shaking (Biscontin and Pestana 2006).

The present work is based on data acquired during three successive oceanographic cruises carried out after the Boumerdès earthquake (Déverchère 2003; Sultan 2004; Savoye 2005). The main aim of this study is to quantify the risk of slope failure during seismic shaking for a study area from the Algerian margin. The main approaches used are: i) characterize numerically and experimentally the mechanical and physical properties of the sediment in order to evaluate the liquefaction potential of the upper sedimentary layers, and ii) assess the presentday slope stability under two different triggering mechanisms (static and cyclic loading) using numerical models.

\section{Geological setting}

Northern Algeria belongs to the Maghrebian chain. From south to north, the Maghrebian chain can be divided into three units: (1) the External domain (Tellian units) composed of sedimentary sequences, mainly marls and limestones; (2) the flysch nappes overthrusting the External domain, and (3) the Internal domain composed of Hercynian basement occasionally associated with its sedimentary cover, the "Dorsale Kabyle", which are relicts of the AlKaPeCa domain (Fig. 1). According to Domzig et al. (2006), the basement of the study area is composed of Oligo-Miocene sediments or flyschs units and probably volcanic deposits. West 
of Algiers, in Khayr al Din bank, the basement probably corresponds to a relict of the Kabylian basement, like nearby Algiers massif.

In the study area, the continental shelf is characterized by a variable width, ranging between $11 \mathrm{~km}$ and $30 \mathrm{~km}$ west of the town of Algiers. East of Algiers, the shelf is almost absent or very narrow with width values between $1 \mathrm{~km}$ and 8 $\mathrm{km}$ (Dan 2007). In the westernmost part of the study area the $500 \mathrm{~m}$ deep elongated plateau of Khayr al Din bank stands above the deep basin by as much as $2700 \mathrm{~m}$ (Fig. 1). The continental slope is steep all over the Algiers area and the 1000 and $2000 \mathrm{~m}$ isobaths are reached at a distance of only $5.5 \mathrm{~km}$ and $10 \mathrm{~km}$ from the coastline respectively. The continental slope is deeply incised by canyons and numerous gullies. Several curved steps or escarpments are visible on the shaded bathymetry map (S1, S2, S3 in Fig. 1 representing the base of each curved escarpment) (Déverchère et al. 2005; Dan 2007). Slide scars and masstransport deposits are rather common particularly at the base of the slope (Dan 2007). The morphology of the continental rise and abyssal plain ranges from flat to rather complex. To be noticed is a deep sea fan off Algiers canyon mouth (D3 in Fig. 1). Several sedimentary basins are bounded by the base of the slope and the deep escarpments (D1, D2, D3 and D4 in Fig. 1) (Déverchère et al. 2005; Domzig et al. 2006). In this work, slope stability assessment will be conducted on the escarpment delimited by the $\mathrm{S} 1$ slope break, which seems to be significantly affected by slope instabilities (Fig. 1). S1 escarpment results from uplift of a faultpropagation fold above a thrust ramp rooted below the Messinian salt layer, which is associated with tilting, still ongoing, of D1 basin (Déverchère et al. 2005). The S1 height is $\sim 350-400 \mathrm{~m}$, indicating an uplift rate of at least $\sim 0.2 \mathrm{~mm} / \mathrm{yr}$, if we refer to the shift of the base of the salt layer (Déverchère et al. 2005). 
Fig. 1

\section{Materials and Methods}

\subsection{Data set and laboratory tests}

Three oceanographic cruises were carried out after the Boumerdès earthquake in the Algiers area: MARADJA (August-September 2003; Déverchère 2003), PRISMA (May-June 2004; Sultan 2004), and MARADJA 2 (NovemberDecember 2005; Savoye 2005). Among the acquired data, two sediment cores (MD04-2799 and KMDJ-16), swath-bathymetric data and side-scan sonar tracks are used for the present study (Fig. 2). Deep-towed side-scan sonar imagery and $3.5 \mathrm{kHz}$ profiles were collected during the MARADJA 2 cruise (Savoye 2005) using the French SAR system (Système Acoustique Remorqué). The S.A.R. sidescan sonar antenna has a frequency of $200 \mathrm{kHz}$ and the vehicle is towed at about $100 \mathrm{~m}$ above the seafloor. During the survey $800 \mathrm{~km}$ of sonar profiles were acquired. In this work we present the SAR profile 10, acquired on the escarpment delimited by the S1 base of slope break (Fig. 2).

Sedimentary and geotechnical analyses were carried out in the IFREMER laboratory in order to define the lithology and to determine the physical and mechanical properties of the sediments. Sediment samples were taken before opening from sediment core MD04-2799, to conduct triaxial cyclic tests and oedometric tests. The triaxial cyclic tests were carried out by FUGRO in order to evaluate the potential for liquefaction of the sediments. Measurements of bulk density or unit weight $(\gamma)$ and the compression wave velocities $(V p)$ were conducted using the Geotek multisensors core logger (MSCL; see http://www.geotek.co.uk). Both cores were longitudinally split, one half being 
used for geological description, photography and X-ray analysis, and the other half for geotechnical measurements. SCOPIX (X-ray) images were made on both sediment cores (MD04-2799 and KMDJ-16) at the University of Bordeaux I. A total of 198 grain-size measurements using a laser analyser COULTER LS130 were conducted on the sediment core subsamples. A motorized mini-vane was used to measure the undrained shear strength, $S u$, every $20 \mathrm{~cm}$ down the sediment cores on clayey sediments only.

Samples were taken from both cores to determine the ages of the sediments using the radiocarbon method. Shells of Globigerinoides and Orbulina planktonic foraminifera, where hand-picked, cleaned in an ultrasonic bath and dried prior to the radiocarbon dating. The absolute date AMS-C14 ages were converted to calendar years before 1950 (BP) using a correction of 400 years for the ocean reservoir age (Reimer et al. 2004).

\subsection{Evaluation of liquefaction potential}

In order to evaluate the liquefaction potential, two primary variables are required: (1) the level of cyclic stress induced by the earthquake on a sediment layer, expressed in terms of Cyclic Stress Ratio (CSR), and (2) the capacity of a sediment layer to resist liquefaction, expressed in terms of Cyclic Resistance Ratio (CRR). Seed and Idriss (1971) formulated the following empirical equation for calculating CSR:

$$
C S R=\frac{\tau_{a v}}{\sigma_{v}^{\prime}} \approx 0.65\left(\frac{a_{\max }}{g}\right)\left(\frac{\sigma_{v}}{\sigma_{v}^{\prime}}\right) r_{d}
$$


where $a_{\max }$ is the peak horizontal acceleration at the surface of the sediment deposit during an earthquake, $g$ is the gravitational acceleration, $\sigma_{v}$ and $\sigma_{v}{ }^{\prime}$ are total and effective overburden stress, respectively, and $r_{\mathrm{d}}$ is a stress reduction factor (Seed et al. 2001).

Evaluation of the CRR was developed along two specific areas of research: methods based on the results of laboratory tests such as cyclic triaxial tests, and methods based on in situ tests and field observations of liquefaction behaviour in earthquakes. In laboratory testing, the number of shear stress cycles to achieve liquefaction is the basis for expressing the resistance of sediment to the initiation of liquefaction. Liu et al. (2001) developed empirical regression equations that can be used to evaluate the number of uniform shear stress cycles of earthquake shaking as a function of magnitude, site-source distance, site conditions, and nearfault rupture directivity effects.

Therefore, based on experimental tests and the number of uniform shear stress cycles evaluated from the diagram of Liu et al. (2001), it is possible to identify the cyclic resistance ratio of the sediment, CRR. The potential for liquefaction can then be evaluated by comparing the earthquake loading (CSR) with the liquefaction resistance (CRR). This is usually expressed as a Factor Of Safety against Liquefaction $\left(\mathrm{FOS}_{\mathrm{L}}\right)$ :

$$
F O S_{L}=\frac{C R R}{C S R}
$$

A $F O S_{L}$ greater than one indicates that the liquefaction resistance exceeds the earthquake loading, and therefore, that liquefaction should not occur.

We also used a more accurate theoretical software, CYCLIC 1D, developed by Elgamal et al. (2002) and Yang et al. (2004) to evaluate the liquefaction potential 
of a sediment under a cyclic loading. CYCLIC 1D is a free Internet-based nonlinear Finite Element program for the execution of one-dimensional site amplification and liquefaction simulations (Yang et al.2004). The input to CYCLIC 1D is a vertical sediment layer profile characterized by its mechanical properties (permeability coefficients, Young's modulus, shear wave velocity, undrained shear strength, unit weight). The unit weight $\gamma$ is obtained from the sediment core using the MSCL. The undrained shear strength $S u$ is measured on the clay sediments using a mini-vane, while the sediment permeability is determined from the oedometer tests. The internal friction angle $\varphi$ ' of the sand beds is estimated from the grain size distribution of the sediment (Das, 1983). The shear wave velocity $V s$ is determined from the following relation:

$$
V_{S}=\sqrt{\frac{G}{\rho}}
$$

where $G$ is the shear modulus and $\rho$ is the sediment mass density $\left(\mathrm{g} / \mathrm{cm}^{3}\right) . G$ is obtained from the slope of the deviatoric stress $(q)$ shear strain $\left(\varepsilon_{s}\right)$ curve inferred from the first cycle of the cyclic triaxial tests.

The accelerogram used for the numerical modelling was recorded onshore during the Boumerdès earthquake, at the Keddara station located $20 \mathrm{~km}$ from the earthquake epicentre (Laouami et al. 2003). Considering this earthquake accelerogram applied at the base of the sediment layer profile, the horizontal acceleration, the displacement, the excess pore pressure, the shear stress, the shear strain and the effective stress are calculated as a function of depth and time during earthquake shaking. From the CYCLIC 1D output, it is therefore possible to evaluate the potential of liquefaction of a sedimentary column. 


\subsection{Slope stability assessment}

The computer program SAMU-3D (Sultan et al. 2007) was used to predict and to evaluate the effect of earthquake shaking on the slope stability. SAMU-3D (slope Stability Analysis Method using Upper bound theorem) was developed for 3D slope stability analysis using the upper bound theorem of plasticity (Chen et al. 2001). The upper bound method requires postulating (1) a valid failure surface which satisfies the mechanical boundary conditions, and (2) a kinematically admissible velocity field which satisfies the boundary conditions and permits the determination of strain rates in the soil delimited by the failure surface.

In SAMU-3D, the proposed equation of the postulated failure surface depends on 8 shape parameters $\left(\alpha, M, \beta, M z, \delta_{1}, \delta_{2}, B, x c\right)$. The failure surface (equation 4$)$ was considered to be as flexible as possible in order to accurately identify the most critical failure surface:

$$
f(x, y, z)=\Psi(\alpha, M, \beta, M z, \delta 1, \delta 2, B, x c)
$$

For the velocity field, the soil is considered as a Mohr-Coulomb material with an associative flow rule. Therefore, the normal velocity $V_{n}$ and tangential velocity $V_{s}$ along the failure surface obey the following relationship:

$$
\mathrm{Vn} / \mathrm{Vs}=-\tan \left(\varphi^{\prime}\right)
$$

where $\varphi^{\prime}$ is the internal friction angle. This implies that the plastic velocity is inclined at an angle $\varphi^{\prime}$ to the failure plane.

One of the outputs of SAMU-3D is the classiocal Factor Of Safety (FOS) so that the results from the proposed model can be directly compared with those from other methods (i.e. limit equilibrium method). FOS values greater than 1 imply 
that the slope is stable, while values lower or equal to 1 imply that the slope is unstable.

For a given external mechanism, the 3D critical failure surface corresponding to the minimum $F O S$, is identified by optimisation with respect to the different shape parameters. The evaluation of the stability of a slope becomes a numerical problem of finding a set of variables that gives the minimum FOS. In SAMU-3D, the probabilistic optimisation method proposed by Chen et al. (2001) was used showing a rapid convergence to the minimum FOS (Sultan et al. 2007).

\section{Results}

\subsection{Morphology of the study area}

The study area, represented by the escarpment delimited by the S1 slope break, is located 20-30 km from the coastline, offshore the town of Dellys (Fig. 1). The escarpment is 350-400 meters high and relatively steep with an average slope angle ranging from $10^{\circ}$ to $15^{\circ}$ (Fig. 2b). Numerous overlapping mass-wasting features with a mean surface value of $0.4 \mathrm{~km}^{2}$ occur along the escarpment (Fig. 2a).

Fig. 2

One sediment destabilisation feature, located in the western part of the escarpment, is $1.7 \mathrm{~km}$ long down dip and $1.8 \mathrm{~km}$ wide across strike (Fig. 2a). The down-slope profile along this feature shows the slide head scarp and a convex area down-slope, assumed to be the mass-wasting deposit (Fig. 2c). The SW-NE across strike section through the same feature depicts the sidewalls and the mass- 
wasting deposit (Fig. 2d). East of this sediment destabilisation feature, a N-S oriented mass-wasting corridor formed by several small slides is observed (Fig. 2a). A collapsed area is visible at the top of the escarpment on the SAR imagery and the $3.5 \mathrm{kHz}$ profile (Fig. 3a). The collapsed area is more than $1 \mathrm{~km}$ long in the NS direction and around 4-6 m deep. The area is covered by bedded parallel reflectors overlain by low amplitude, transparent seismic facies with good lateral continuity (Fig. 3b).

Fig. 3

Further down-slope, the SAR imagery shows evidence of mass-wasting (Fig. 4a). The $3.5 \mathrm{kHz}$ profile associated to the SAR image shows slided material on the lower part of the slope (Fig. 4b). Up to three successive failure surfaces may be identified on the $3.5 \mathrm{kHz}$ profile (Fig. 4b). The geometry of the slide suggests that the erosional feature identified on the sonograph may correspond to a retrogressive slide. The area is characterized by a rough, non penetrative seismic facies, indicating the presence of coarse material and/or eroded character of the slope. A convex feature observed at the bottom of the slope is interpreted as a mass-wasting deposit whose maximum thickness, estimated from the $3.5 \mathrm{kHz}$ profile, is about 25-30 meters (Fig. 4b). Parallel well stratified reflectors cover the D2 basin at $2700 \mathrm{~m}$ water depth (Fig. 4b).

Fig. 4

\subsection{Sedimentary and geotechnical description}

The two sediment cores recovered from the top of the S1 escarpment were analysed in order to characterize the physical and the geotechnical properties of 
intact sediment (Fig. 2b). The $8.67 \mathrm{~m}$ long KMDJ-16 sediment core was recovered at $2259 \mathrm{~m}$ water depth. From the top to $4.2 \mathrm{mbsf}$ the core is manly composed of silty-clay sediments, while from $4.2 \mathrm{~m}$ to the bottom the sediment consists of $1 \mathrm{~cm}$ to $5 \mathrm{~cm}$ thick fine to medium sand turbidites alternating with brown clayey hemipelagic units (Fig. 5a).

Fig. 5

$\mathrm{X}$-ray images obtained at different depths illustrate sedimentary structures within the sand layers such as upward and downward migration of the sand into the siltyclay sediment (Fig. 6a), discontinuous layers (Fig. 6b and 6c) and parallel lamination (Fig. 6d). Grain size measurements carried out between 7.35 and 7.62 mbsf revealed the predominance of fine sand within the turbidite layers (Fig. 6e).

Fig. 6

The unit weight $\gamma$ measurements carried out on the sediment core KMDJ-16 show an average value of $17 \mathrm{kN} / \mathrm{m}^{3}$ from the core top down to $4 \mathrm{mbsf}$ (Fig. $5 \mathrm{c}$ ), while underneath $\gamma$ ranges from 17 to $21 \mathrm{kN} / \mathrm{m}^{3}$. Vp measurements carried out using the MSCL show a relatively constant values close to $1500 \mathrm{~m} / \mathrm{s}$ for the upper $4 \mathrm{~m}$ of sediment, and between 1500 and $1850 \mathrm{~m} / \mathrm{s}$ (Fig. 5d) for the core lower part. These high $\gamma$ and $V p$ values are clearly related to the presence of sandy intervals beneath 4 mbsf. The undrained shear strength $S u$ of clayey sediments shows a relative increase with depth, with maximum values of $12 \mathrm{kPa}$ towards the core bottom (Fig. 5e).

Sediment core MD04-2799 is $25.3 \mathrm{~m}$ long (Fig. 7a) and was recovered in $2248 \mathrm{~m}$ water depth. The upper most part of the sediment core, from the top down to 4.5 
mbsf, is dominated by silty-clay, up to $80 \%$ (Fig. 7b). In contrast, very thin silt and fine to medium sand layers alternate with silty-clay intervals beneath 4.5 mbsf. The thickness of the silt and sand layers ranges from 0.2 to $4 \mathrm{~cm}$ in thickness. Since sand layers often show erosional bases and fining upward trends, we interpret them as turbidite deposits. Turbidites thin till disappearing towards the core bottom. Evidence of deformation within the sand layers is also visible on the X-ray images (Fig. 7f). Sediment core MD04-2799 is characterized by $\gamma$ ranging between 14 and $16 \mathrm{kN} / \mathrm{m}^{3}$ for the upper part (from 0 to $4.5 \mathrm{mbsf}$ ), smoothly increasing with depth below 4.5 mbsf (Fig. 7c). $V p$ ranges from 1500 to $1520 \mathrm{~m} / \mathrm{s}$ for the upper $5 \mathrm{~m}$ (Fig. 7d), from where it slightly increases with core depth, reaching $1570 \mathrm{~m} / \mathrm{s}$ at $8 \mathrm{mbsf}$ (Fig. 7d). The vane shear test measurements show a linear increase of the $S u$ with depth, with a peak of $28.6 \mathrm{kPa}$ at $24.4 \mathrm{mbsf}$ (Fig. 7e).

Fig. 7

${ }^{14} \mathrm{C}$ dating gave an average age of 9033 years is estimated at $3.9 \mathrm{mbsf}$ for sediment core MD04-2799 (Table 1). Assuming constant sediment accumulation through time, the mean sedimentation rate could be estimated at $43 \mathrm{~cm} / \mathrm{ky}$ for the upper part of this sediment core. Two radiocarbon dates are available for the sediment core KMDJ-16 at 0.2 and $4.2 \mathrm{mbsf}$ (Table 1), which results in a sedimentation rate of $31 \mathrm{~cm} / \mathrm{ky}$ for the upper part of this second sediment core.

Table 1

\subsection{Geotechnical analysis}

\subsubsection{Oedometers tests}


Both sediment cores, KMDJ-16 and MD04-2799, were whole-round sampled at several depth intervals (see white rectangles in the left core log column in Fig. 5a and Fig. 7a) to carry out oedometer tests, 7 on samples from MD04-2799 and 3 on samples from KMDJ-16 (Table 2 and Fig. 8).

Table 2

Void ratio $(e)$ vs. the vertical effective stress $\left(\sigma_{v}^{\prime}\right)$ diagrams for the samples taken at 2.24 mbsf and $3.95 \mathrm{mbsf}$ from MD04-2799 and at 0.83, 1.85 and $2.85 \mathrm{mbsf}$ from KMDJ-16 are shown in Fig. 8a.

Fig. 8

The Over Consolidation Ratio, $O C R=\sigma_{p}^{\prime} / \sigma_{v}^{\prime}$, where $\sigma_{p}^{\prime}$ is the preconsolidation stress inferred from the oedometer tests reveals the consolidation state of the siltyclay intervals from the upper part of the sediment cores (Fig. 9). One $O C R$ value from KMDJ-16 is found to be greater than 1 at $0.83 \mathrm{~m}$ depth, indicating a relatively high overconsolidation state of the uppermost sediments. Three other values are equal or slightly less than 1 , while one $O C R$ is equal to 0.57 at 2.85 mbsf (Table 2). Figure $8 \mathrm{~b}$ presents the results of five oedometer tests carried out on MD04-2799 samples at 7.42, 12.18, 15.57, 18.42 and 23.60 mbsf. For the sediment samples located beneath $4.5 \mathrm{~m}$, all $O C R$ values are less than 1 , which is indicative of underconsolidation (Fig. 9).

Fig. 9

\subsubsection{Cyclic triaxial tests}

Twelve cyclic triaxial tests were carried out on sediment samples from MD042799 (Table 3). For each cyclic test, we plotted the following parameters: (a) the 
changes of the $C R R$ which is expressed as the cyclic stress ratio amplitude $\left(C R R=\sigma_{d, c y c} / 2 \sigma_{3 c}^{\prime}\right.$ where $\sigma_{d, c y c}$ is the cyclic deviatoric stress and $\sigma_{3 c}^{\prime}$ is the effective minor principal stress at the end of consolidation); (b) the vertical strain $\left(\Delta h / h_{c}\right)$, where $\Delta h$ is the axial deformation and $h_{c}$ is the initial height of the sample; and (c) the excess pore pressure $\Delta u$ normalised with respect to $\sigma_{3 c}^{\prime}$ $\left(\Delta u / \sigma_{3 c}^{\prime}\right)$ as a function of the number of cycles $N$ (Fig. 10). The analysis of the cyclic tests results allowed us to characterise the sediment failure and/or liquefaction process under cyclic loading in two different ways, as illustrated by tests VI-I and IX-2 that are presented hereafter. Figure 10a illustrates the three previously mentioned parameters for the test VI-1 (8.47 - $8.62 \mathrm{mbsf})$, where the cyclic deviatoric stress, $\sigma_{d, c y c}$, could not be maintained during the triaxial cyclic test. This sudden drop of $\sigma_{d, c y c}$ is most likely related to the behaviour of the sample VI-1 sediment, which mean grain size is fine silt $(5.43 \mu \mathrm{m})$. Arulmoli et al. (1992) published similar sediment behaviour for Binnie silt (samples CYBS-24, CYBS31 and CYBS-32), where the cyclic deviatoric stress could not be maintained also during the triaxial cyclic test. As a first definition of failure, we note that a high vertical strain, $\Delta h / h_{c}$, exceeds $10 \%$ after 15 cycles (Fig. 10a).

Fig. 10

Table 3

The second type of failure is illustrated by the results of the triaxial cyclic test IX2 performed on sediment located at 12.35-12.5 mbsf (Fig. 10b). The excess pore pressure exceeding $90 \%$ of $\sigma_{3 c}^{\prime}$ took place after only 5 cycles (Fig. 10b) and we define this result as "liquefaction". A decrease of the deviatoric stress was also observed during this triaxial cyclic test (Fig. 10b). 
Experimental results obtained from the 12 cyclic tests were used in order to draw the variation of CRR as a function of the cycles to failure/liquefaction. We found two ways of failure/liquefaction characterizing the Algerian sediment (Fig. 11a): (1) upper bound (failure) shown by grey diamonds representing samples where liquefaction is reached for $\Delta u / \sigma_{3 c}^{\prime}>0.90$; and (2) lower bound shown by black dots correspond to the samples where failure is reached for a decrease of $40 \%$ of the $\sigma_{d, c y c} / 2 \sigma_{3 c}^{\prime}$ applied initially.

Fig. 11

For this second type of sediment failure (criteria based on $\sigma_{d, c y c} / 2 \sigma_{3 c}^{\prime}$ ), liquefaction was suspected to occur locally in a silty-sandy layer of a heterogeneous sample as it can be observed in Fig. 12. This failure could correspond to a localized liquefaction of the sandy layer which was not recorded by the pore pressure sensors, since they are connected to the top and the bottom of the sample. In this work the use of the drop in the cyclic deviatoric stress as a criterion for the definition of the failure/liquefaction of the sediment was adopted instead of strain criteria because of the tiny thickness $(2 \mathrm{~mm})$ of the silty-sandy layer (Fig. 12): an important local deformation in this tiny sandy-silty layer will cause a limited total deformation of the sample but an important drop in the cyclic deviatoric stress.

Fig. 12

\subsection{Liquefaction potential}

The sedimentary description of the two cores, MD04-2799 and KMDJ-16, revealed the presence of numerous sandy layers, which are highly susceptible to 
liquefaction during an earthquake. When saturated granular sediment is exposed to strong earthquake ground shaking, the grains have a tendency to compact, squeeze together, and reduce volume. Since the duration of the cyclic loading is too short to allow the drainage of water, a decrease in the effective confining stress and a subsequent increase of equal magnitude in the pore water pressure will occur. When the sand is loose enough and the magnitude of the cyclic shear stress is high enough, the vertical effective stress drops to zero (i.e. Ishihara 1985) and liquefaction is reached.

To evaluate the liquefaction potential we applied the method of the $F O S_{L}$ (Seed et al., 2001), previously described. The liquefaction potential was evaluated for an earthquake of $\mathrm{M}_{\mathrm{w}}=6.8$ (i.e. similar to the Boumerdès earthquake) and a sediment located at $25 \mathrm{~km}$ from the epicentre ( $\mathrm{S} 1$ escarpment is located $25-30 \mathrm{~km}$ off the Boumerdès earthquake epicentre). The $F O S_{L}$ calculated for different values of Peak Ground Acceleration (PGA $=0.10 \mathrm{~g}, 0.15 \mathrm{~g}, 0.20 \mathrm{~g}$ and $0.25 \mathrm{~g}$, where $\mathrm{g}$ is the gravitational acceleration) is plotted vs. core depth for the different subsections where cyclic tests were conducted between 7 and 17 mbsf in core MD04-2799 (Fig. 11b). For a PGA of $0.10 \mathrm{~g}$ and $0.15 \mathrm{~g}$, the $F O S_{L}$ is always greater than 1, while a $F O S_{L}$ equal to 1 is found for a PGA of $0.20 \mathrm{~g}$ at 7 and 17 mbsf (Fig. 11b). In this calculation the initial under-consolidation state of the sediment shown in Figure 9 was considered only as expressed by the geotechnical properties in Table 4, which represent a synthetic profile made of 18 layers. This profile was defined from the geological and geotechnical laboratory tests carried out on both sediment cores (Table 4).

Table 4 
The accelerogram recorded onshore during the Boumerdès earthquake at the Keddara station, $20 \mathrm{~km}$ from the epicentre (Laouami et al. 2003), is applied at the base of a sedimentary column that we placed at $40 \mathrm{mbsf}$. In the lack of data about bedrock depth and sediment properties below layer 18, we assume that the unit weight between layer 18 and the bedrock is high enough to conserve the accelerogram recorded at the Keddara station.

Based on the diagram given by Idriss (1985), where the PGA is given as a function of the earthquake magnitude (M) and the distance to the epicentre $(d)$, we can estimate the PGA induced by the Boumerdès earthquake $\left(\mathrm{M}_{\mathrm{w}}=6.8\right)$. For an area located $25-30 \mathrm{~km}$ from the earthquake epicentre and a $\mathrm{M}_{\mathrm{w}}$ of 6.8 , the induced PGA ranges between $0.15 \mathrm{~g}$ and $0.2 \mathrm{~g}$. The results of the numerical modelling obtained using CYCLIC 1D for PGAs of $0.1 \mathrm{~g}$ and $0.2 \mathrm{~g}$ are presented in Figure 13. The horizontal accelerations induced by the two levels of shaking, 0.1 $\mathrm{g}$ and $0.2 \mathrm{~g}$, show curves with a similar trend, with an amplification of the horizontal acceleration at the upper part of the sedimentary column. The horizontal acceleration remains quasi constant between 20 and $40 \mathrm{mbsf}$ for the two applied values of PGA, confirming our initial hypothesis about the preservation of the accelerogram for a high unit weight (Fig. 13a). Regarding the excess pore pressure predicted from the two numerical models, a significant increase of the excess pore pressure in the sand and silt layers is clearly evidenced (Fig. 13b). For a PGA of $0.1 \mathrm{~g}$ a maximum excess pore pressure of $23.7 \mathrm{kPa}$ is reached between 8 and 10 mbsf, while it almost doubles at the same depth with a PGA of $0.2 \mathrm{~g}$.

Fig. 13 
While a decrease of the vertical effective stress is observed in the sand and silt layers for a PGA of $0.1 \mathrm{~g}$, this parameter reaches zero at 5 and $7 \mathrm{mbsf}$ for an earthquake with a PGA of $0.2 \mathrm{~g}$ (Fig. 12c). Therefore, from the numerical calculations carried out using CYCLIC 1D it comes out that sand and silt layers from cores KMDJ-16 and MD-2799 are susceptible to liquefaction under an earthquake characterized by a PGA of $0.2 \mathrm{~g}$. This finding is in good agreement with the results obtained after Seed's et al. (2001) method.

\subsection{Slope stability assessment (SAMU-3D)}

Numerical calculations were conducted in order to evaluate the slope stability in a zone west of the location of sediment core MD04-2799 (Fig. 14a). This zone is characterized by a mean slope gradient of $5^{\circ}$ (Fig. 2b) and we assume it is the only zone not affected by gravitational processes in the whole study area.

Fig. 14

To perform the 3D-slope stability assessment the 18 layers model used for the CYCLIC 1D simulation was simplified into nine parallel sediment layers (Table 5). Two calculations based on two different scenarios were performed for this zone.

Table 5

The first scenario considers the slope stability under static conditions. Only the static physical properties of the sediments (unit weight, internal friction angle and undrained shear strength) are considered. When sediment is sheared under an applied stress, the produced excess pore pressure may (drained conditions) or may 
not (undrained conditions) escape depending on the permeability of the sediment and the time available. Under gravity loading, both drained and undrained conditions are considered. However, under such situation, failure probably occurs under drained conditions, which typically generate higher shear strength and therefore higher FOS. Slope stability assessment under gravity loading includes both total stress (undrained conditions) and effective stress (drained conditions) analyses with the aim of determining under which conditions the sediment is less stable. The internal friction angle of the clay was not determined experimentally in this work, but we considered typical values from literature (Das 1983).

The second scenario concerns the slope stability evaluation under an earthquake, where applied loading conditions are estimated from the results of the CYCLIC 1D simulation (Table 5). For this dynamic scenario, slope failure is assumed to occur under undrained conditions because earthquake loading is rapid and the excess pore pressure does not have enough time to dissipate.

\subsubsection{Slope stability assessment under static loading}

An optimization procedure step, such as the one described by Sultan et al. (2007), has been used to find the minimum FOS and the most critical failure surface. Under undrained conditions, 25,000 calculations were necessary to obtain the minimum FOS, which is equal to 1.45 and which indicates that the slope is stable under undrained conditions (Fig. 15a). However, if failure occurs, a critical failure can be predicted and was projected on the shaded bathymetric map (red area in Fig. 14b). Its surface is $0.82 \mathrm{~km}$ long and $0.40 \mathrm{~km}$ wide (Fig. 16a). Figure $16 \mathrm{~b}$ presents the cross section through the predicted failure surface along the Neutral 
Line (NL, symmetry axis of the failure surface) and shows a maximum depth of the failure surface of $30 \mathrm{~m}$ that is similar to the height of the headscarps observed on the seafloor morphology.

Fig. 15

A second calculation was carried out under drained conditions with a $\varphi^{\prime}$ value of $25^{\circ}$ for silty-clay deposits. The FOS is found equal to 5.5 (Fig. 15b), which is almost 4 times higher than the FOS obtained for undrained conditions.

\subsubsection{Slope stability assessment under cyclic loading}

In SAMU-3D, the horizontal acceleration generated by an earthquake is modelled using a pseudo-static method, in which the inertial force caused by ground acceleration is applied as an effective static load (Pestana et al. 2000). For the present scenario, the 3D slope stability assessment is carried out by taking into account only the average value of the horizontal acceleration obtained with the CYCLIC 1D software, which represents $50 \%$ of the PGA. The increase of the excess pore pressure under an earthquake into the silt and sand layers is very significant. The excess pore pressure derived from CYCLIC 1D modelling shows that under a PGA of $0.2 \mathrm{~g}$ liquefaction may be triggered in shallow silty-sandy deposits, while for a PGA of $0.1 \mathrm{~g}$ the excess pore pressure is about $50 \%$ of the lithostatic stress at around $5 \mathrm{mbsf}$.

For the present scenario and for a PGA of $0.1 \mathrm{~g}$ (horizontal acceleration of $0.05 \mathrm{~g}$ ), a $F O S$ equal to 1.01 was obtained after 25,000 step calculations. Then, an earthquake characterized by a PGA of $0.1 \mathrm{~g}$ is enough to generate a slope failure 
in the area under consideration (Fig. 15c). The most critical failure surface (lowest FOS) for earthquake loading is projected in Figure 14b, and corresponds to a $1.19 \mathrm{~km}$ long and $0.43 \mathrm{~km}$ wide surface (Fig. 16c). The maximum thickness of the failure surface is obtained from the cross section through the predicted failure surface along the NL and it is about $30 \mathrm{~m}$ (Fig. 16d). Such a surface is comparable to the headscarp values of the observed landslides.

Fig. 16

\section{Discussion}

\subsection{Depositional setting}

Sediment cores MD04-2799 and KMDJ-16 are located on both sides of the slide corridor, as observed in Figure 2. Both sediment cores were used as references for physical and geotechnical properties of the non-destabilised sediment from the study area. Based on the sediment's analyses, the depositional setting appears to be similar on both sides of the corridor. The upper part of the sediment cores deeper than 4.2-4.5 mbsf, consists of silty-clays deposits contrasting with the lower part of the cores (deeper than 4.2-4.5 mbsf), where thin silty and sandy turbidites alternate with silty-clay intervals. Accordingly, the sediment depositional pattern seems to have changed at the time of $4.2-4.5 \mathrm{mbsf}$ for both MD04-2799 and KMDJ-16 sediment cores.

The average sedimentation rates derived from the ${ }^{14} \mathrm{C}$ datations (see Section 4.2) can be used to reconstruct the sedimentation history on the study area. Turbidity currents apparently stopped at about the same time at the sites of cores since both cores show a $>4 \mathrm{~m}$ thick hemipelagic unit above the lower turbidite unit. Two 
mutually compatible scenarios may explain the absence of the turbidites in the upper core sections 4.2-4.5 mbsf.

The first scenario considers the role played by post-glacial sea-level change. Results from the radiocarbon dating enable to estimate that turbidity currents activity stopped between 10,000 and 13,000 years BP (Table 1). During the previous glacial sea level low stand, paleo-Sebaou and Isser Rivers crossed the exposed continental shelf and discharged sediment directly onto continental slope (Fig. 17a). In contrast, during sea level rise (present day situation) sediments are trapped on the continental shelf. During high stands, as at present, no sediment or almost no sediment escapes off shelf as bedload.

The second scenario considers the significant role played by local tectonics, as represented by the emergence of the $\mathrm{S} 1$ escarpment (Fig. 17b). Both cores are presently located 100 meters above the D1 basin and 400 meters above the D2 basin. Assuming that the youngest turbidite dates the escarpment emergence, the rate of elevation for a constant sedimentation rate of $36 \mathrm{~cm} / 1000$ years can be estimated at $2.5 \mathrm{~cm} /$ year. This rough estimation is 100 times higher than the value found by Déverchère et al. (2005).

Fig. 17

In practise, the combination of sea level rise and local uplift (Fig. 17b) could explain the character of the sedimentary succession in cores MD04-2799 and KMDJ-16, with the abrupt shift from turbidite-dominated to hemipelagitedominated intervals immediately before the start of the Holocene.

\subsection{Characteristics and setting of slides}


From a morphological view, the slides observed along the S1 escarpment seem to correspond to cohesive slides. The term cohesive slide was defined by Hampton et al. (1996) as slope failures with allochthonous material from the failure occurring near the headscarp, i.e. with limited downslope displacement. The mean volume of the sediment involved into the slides is about $6.10^{6} \mathrm{~m}^{3}$. Slope failures initiated at various locations on the S1 escarpment. Headscarps do not coincide with the maximum slope gradients (Fig. 2b), thus indicating that steepness is not a major parameter controlling the initiation of slides in the study area. The minor effect of the slope gradient on the initiation of slides have been mentioned previously in the literature (Hampton et al. 1996; Booth et al. 1993; McAdoo et al. 2000; Canals et al., 2004; Sultan et al. 2004; Hühnerbach and Masson 2004; Lastras et al. 2006). The slides may initiate on weak layers, which in our case correspond to thin silt and sand layers. The collapsed area observed atop of the escarpment is probably linked to the disturbance of silt and sand layers which could act as weak layers.

\subsection{Factors promoting slope failures}

Slope failures initiate when downslope driving forces exceed the resisting forces. Several factors may be considered responsible for the initiation of slope failures (Hampton et al. 1996; Locat and Lee 2002), although in the present study the main pre-conditioning factor is the presence of silt and sand layers, as previously mentioned, and the most likely triggering factor is earthquake shaking.

Earthquake-induced liquefaction is initiated in the silt and sand layers, generating high excess pore pressures (Fig. 13b). The triaxial cyclic tests and numerical

modelling carried out in order to evaluate the liquefaction potential of the 
Algerian sediment showed that liquefaction appears in sand and silt layers with an earthquake generating a PGA of $0.2 \mathrm{~g}$ (Fig. 11b, 13c). Generally, cyclic triaxial tests are carried out in homogeneous sediments. In contrast, our tests were made on heterogeneous sediment, in order to characterize the mechanical behaviour of the thin silt and sand layers alternating with silty clays. The laboratory tests showed that liquefaction occurs in the thin silt/sand layers, despite the triaxial cell sensors did not record a significant increase of the pore pressure.

Disturbance of the sand layers, including sand injections into adjacent sediment, discontinuous lamination and massive remoulded structures were revealed on the X-ray images of both sediment cores, MD04-2799 and KMDJ-16. The upward sand injections are probably due to liquefaction and excess pore pressure could be the cause of the observed collapses in the study area. Evidence of seafloor collapse was detected on the $3.5 \mathrm{kHz}$ seismic profile (Fig. 3b), on top of the S1 escarpment and near MD04-2799 core location. Beyond the liquefaction process, the excess pore pressure generated by a seismic event may migrate during or shortly after the time of the earthquake shaking and can be trapped under layers characterized by slower dissipation of pore pressure. The result may be a decrease in effective stress and in stiffness or strength, which could cause larger deformations that otherwise may not be present (Biscontin and Pestana 2006).

Both sediment cores, KMDJ-16 and MD04-2799, are characterized by complex consolidation histories. Possibly, the underconsolidation state of the sediment could be related to the relatively high sedimentation rate (see Section 4.2), while overconsolidation state could be related to erosion. The consolidation state along the sediment core KMDJ-16 decreases with depth (Fig. 9), while the core MD042799 shows normally consolidated sediment downcore to $7.42 \mathrm{mbsf}$ and 
underconsolidated sediment between 12 and 23 mbsf (Fig. 9). In none of the two cores the sediment consolidation state did not fit with a coherent sedimentation history (i.e. a uniform trend of consolidation state) which makes us believe that the underconsolidation relates to a secondary process, such as earthquake loading (with or without full liquefaction), and not to the sediment deposition history itself. The excess pore pressure generated in sandy-silty layers by an earthquake loading may migrate upward into more clayey sediments. Also, the excess pore pressure generated during seismic loading reduces significantly the $O C R$ of the sand layers, which tend to zero under liquefaction. Therefore, the $O C R$ of the silty clay deposits in contact with the sand layers may decreases significantly. Sediments from cores MD04-2799 and KMDJ-16 are characterized by $O C R$ values ranging from 0.52 to 0.61 indicating that pore pressure may have been generated directly or indirectly by earthquake shaking. From the consolidation state of MD04-2799 and KMDJ-16 and the relatively high OCR values (with respect to 0 corresponding to liquefaction state), we argue that during the last Boumerdès earthquake liquefaction didn't occur at these two sites. The observed excess pore pressure and sediment disturbance probably corresponds to a cumulative effect of previous seismic events.

The calculation results obtained from SAMU-3D software show that the slope is less stable under undrained conditions. The study area is characterized by a FOS equal to 1.45 under undrained conditions and static loading, decreasing to 1.01 under cyclic loading. This implies that slope failure may occur during an earthquake generating a PGA equal to $0.1 \mathrm{~g}$. A maximum PGA of $0.1 \mathrm{~g}$ would correspond to an earthquake of magnitude 5.9 to 6.3 , occurring at $25-30 \mathrm{~km}$ from the study area and similar to the Boumerdès event of 2003. The disagreement between the observed morphology, the measured OCR showing that the 2003 
earthquake event didn't generate sediment liquefaction at the study site, and the SAMU-3D calculation results is probably related to the pseudo-static method used in SAMU-3D. According to Pestana et al. (2000) the use of the pseudo-static method is not always diagnostic since a FOS less than 1 does not necessarily imply slope failure with a large displacement of the slided mass. The geometry of the layers represents another limitation for the slope stability assessment since we considered the layers as parallel to the seafloor and continuous all over the study area. Our findings show that slope failure did not accur during the 2003 Boumerdès earthquake at the locations of the two sediment cores studied, but this does not mean that failure was not triggered in other locations of the Algiers continental margin during the same event.

\section{Conclusions}

The main porpose of our study was to relate coarse-grained sediments with slope instability in the earthquake prone Algerian margin. To achieve this we have applied different methods whose main results are the provided below.

The morphological analysis of the seafloor revealed the presence of numerous destabilized areas along the S1 escarpment in the Algerian continental slope about $30 \mathrm{~km}$ far from the $\mathrm{Mw}=6.82003$ Boumerdès earthquake. Slope destabilization dinvolved several cohesive landslides with a mean surface of $0.4 \mathrm{~km}^{2}$.

Numerous thin silt and sand layers were observed in the two available sediment cores, MD04-2799 and KMDJ-16, which are susceptible to liquefaction and could behave as "weak" layers during an earthquake. Moreover, sedimentary structures such as sand injections into the overlying sediment and lateral thickness variations 
of the sand layers identified in X-ray images are likely associated with the liquefaction of the sand layers.

The laboratory geotechnical measurements showed the underconsolidated nature of the sediment at different core depths, which is likely associated with the sand layers sensitivity to earthquake loading in terms of excess pore pressure and diffusion of the high excess pore pressure into the overlying silty clay deposits. However, the OCR profile indicates that the disturbance identified in the cores' sediments are not linked to liquefaction generated by the 2003 Boumerdès earthquake.

The numerical calculations using CYCLIC 1D and the Seed and Idriss (1971) empirical model show that liquefaction of the shallow sandy-silty layers may occur during an earthquake characterized by a PGA of $0.2 \mathrm{~g}$.

The calculation results using SAMU-3D show that the study area is characterized by a FOS equal to 1.45 under static, undrained loading, which decreases to 1.01 under cyclic loading, implying that failure may occur during an earthquake similar to the Boumerdès earthquake. The disagreement between SAMU-3D results and the other observations indicating that the study area was not failed during the Boumerdès earthquake is probably related to the use of the pseudo-static method in SAMU-3D and to the layer geometry that we considered as parallel to the seafloor, which could have led to underestimating the FOS. On the other hand, the shape of the most critical failure surface predicted from the numerical modelling is similar to the shape and size of slides in the study area, which confirms that earthquake failure mechanism could account for the present morphology of the study area. 
To better predict future failure in this area, we need a better knowledge of the spatial extent of the sand layers is required. Heterogeneity of the sandy layers could have locally a great impact on sediment stability and also could explain the small size of the observed slides. More knowledge of the spatial and temporal pore pressure variations in sandy layers during earthquakes, in-situ piezometer monitoring during or after earthquakes are also required. Dating of the observed landslides by coring at the location of the exposed scars and landslide deposits in search for sediment layers post-dating failure events is also needed to improve our understanding of the frequency of events and relationships between earthquakes and slide initiation along the Algerian margin.

Acknowledgements

This work has been developed within the EURODOM European Project (contract RTN2-200100281). Financial support was provided by IFREMER and the Agence Nationale de Recherche (ISIS project). The support by officers and crew during MARADJA 2003, PRISMA and MARADJA 2 cruises is greatly appreciated. The authors thank E. Gràcia, H. Lee and M. Canals for their comments and suggestions that significantly improved the paper.

References

Arulmoli K, Muraleetharan KK, Hosain MM, Fruth LS (1992) VELACS Laboratory Testing Program, Soil Data Report, The Earth Technology Corporation, Irvine, California, Report to the National Science Foundation, Washington D.C., March 77 pp.

Baptista MA, Miranda PMA, Miranda JM, Mendes Victor L (1998) Constrains on the source of the 1755 Lisbon tsunami inferred from numerical modelling of historical data, Journal of Geodynamic25(2): 159-174.

Biscontin G, Pestana JM (2006) Factors affecting seismic response of submarine slopes. Natural Hazards and Earth System Sciences 6: 97-107.

Booth, J.S., O'Leary, D.W., Popenoe, P., Danforth, W.W., 1993. U.S. Atlantic continental slope landslides: their distribution, general attributes, and implication. In: Schwab, W.C., Lee, H.J., Twichell, D.C. (Eds.), Submarine landslides: Selected Studies in the U.S. Exclusive Economic Zone, U.S. Geological Survey Bulletin 2002: 14-22.

Bounif A, Dorbath C, Ayadi A, Meghraoui M, Beldjoudi H, Laouami N, Frogneux M, Slimani A, Alasset PJ, Kharroubi A, Ousadou F, Chikh M, Harbi A, Larbes S, Maouche S (2004) The 21 May 2003 Zemmouri (Algeria) earthquake Mw 6.8: Relocation and aftershock sequence analysis. Geophysical Research Letters 31(L19606, doi:10.1029/2004GL020586). 
Canals M, Lastras G, Urgeles R, Casamor JL, Mienert J, Cattaneo A, De Batist M, Haflidason H, Imbo Y, Laberg JS, Locat J, Long D, Langva O, Masson DG, Sultan N, Trincardi F, Bryn P (2004) Slope failure dynamics and impacts from seafloor and shallow sub-seafloor geophysical data: case studies from the COSTA project, Marine Geology 213: 9-72.

Chen Z, Wang X, Haberfield C, Yin J, Wang Y (2001) A three-dimensional slope stability analysis method using the upper bound theorem, Part I: Theory and methods. International Journal of Rock Mechanics and Mining Sciences 38: 369-378.

Dan G (2007) Processus gravitaires et évaluation de la stabilité des pente: approche géologique et géotechnique. Application à la marge algérienne et à l'effondrement de l'aéroport de Nice en 1979, Ph-D Thesis, UBO, 2007, 365 pp.

Das BM (1983) Advanced Soil Mechanics, Taylor and Francis Publisher, 425 pp.

Déverchère J (2003) MARADJA cruise report, IUEM.

Déverchère J, Yelles K, Domzig A, Mercier de Lépinay B, Bouillin JP, Gaullier V, Bracène R, Calais E, Savoye B, Kherroubi A, Le Roy P, Pauc H, Dan G, 2005. Active thrust faulting offshore Boumerdès, Algeria, and its relations to the 2003 Mw 6.9 earthquake. Geophysical Research Letters 32(L04311).

Domzig A, Yelles K, Le Roy C, Dévercère J, Bouillin JP, Bracène R, Mercier de Lépinay B, Le Roy P, Calais E, Kherroubi A, Gaullier V, Savoye B, Pauc H (2006) Searching for the AfricaEurasia Moiocene boundary offshore western Algeria (MARADJA '03 cruise). Comptes Rendus Geoscience 338: 80-91.

Elgamal A, Yang Z, Parra E (2002) Computational modeling of cyclic mobility and post liquefaction site response. Soil Dynamics and Erathquake Engineering 22: 259-271.

Finn WDL (1981) Liquefaction potential: developments since 1976. In: Proceedings of the 1st International Conference of Recent Advances in Geotechnical Earthquake Engineering and Soil Dynamics; St Louis 2; S. Prakash (Ed.), University of Missouri-Rolla, 655-681.

Gennesseaux M, Mauffret A, Pautot G (1980) Les glissements sous-marins de la pente continentale niçoise et la rupture des câbles en mer Ligure (Méditerranée occidentale). Comptes Rendus de l'Académie des Sciences Paris 290.

Gracia E, Danobeitia JJ, PARSIFAL Team (2003) Mapping active faults offshore Portugal $\left(36^{\circ} \mathrm{N}-\right.$ $\left.38^{\circ} \mathrm{N}\right)$ : implications for seismic hazard assessment along the southwest Iberian margin. Geology 31(1): 83-86.

Hampton MA, Lee HJ, Locat J (1996) Submarine landslides. Reviews of Geophysics 34: 33-59.

Heezen BC, Ewing M (1952) Turbidity currents and submarine slumps, and the 1929 Grand Banks earthquake. American Journal of Science 250: 849-873.

Hühnerbach V, Masson DG (2004) Landslides in the North Atlantic and its adjacent seas: an analysis of their morphology, setting and behaviour. Marine Geology 213: 343-362.

Idriss IM (1985) Evaluating seismic risk in engineering practice. 11th International Conference of soil mechanics and foundation engineering; San Francisco 1: 255-320.

Ishihara K (1984) Post-Earthquake Failure of a Tailings Dam due to Liquefaction of the Pond Deposit. Proceedings International Conference on Case Histories in Geotechnical Engineering. St Louis, Missouri 3: 1129-1143.

Ishihara K (1985) Stability of Natural Deposits During earthquakes. 11th International Conference of soil mechanics and foundation engineering, Proceedings, San Francisco 1: 321-376. 
Ishihara K (1993) Liquefaction and flow failure during earthquake. The 33rd Rankin Lecture. Geotechnique 43(3): 351-415.

Kramer SL (1996) Geotechnical Earthquake Engineering, Prentice Hall, New Jersey. 653 pp.

Laouami N, Slimani A, Bouhadad Y, Nour A, Larbes S (2003) Analysis of Strong Ground Motions Recorded during the 21st May, 2003 Boumerdès, Algeria, Earthquake, CSEM Newsletter 20: $5-7$.

Lastras G, Canals M, Amblas D, Ivanov M, Dennielou B, Droz L, Akhmetzhanov A, TTR-14 Leg 3 Shipboard Scientific Party (2006) Eivissa slides, western Mediterranean Sea: morphology and processes. Geo-Marine Letters 26: 225-233.

Liu AH, Stewart JP, Abrahamson NA, Moriwaki Y (2001) Journal of Geotechnical Geoenvironmental Engineering 127(12): 1017- 1026.

Locat J, Lee HJ (2002) Submarine landslides: advances and challenges. Canadian Geotechnical Journal 39: 193-212.

Marcuson III WF (1978) Definition of terms related to liquefaction, Journal of Geotechnical Engineering Division, ASCE, 104(9): 1197-1200.

McAdoo BG, Pratson LF, Orange DL (2000) Submarine landslide geomorphology, US continental slope. Marine Geology 169: 103-136.

Meghraoui M, Maouche S, Chemaa B, Cakyr Z, Aoudia A, Harbi A, Alasset PJ, Ayadi A, Bouhadad Y, Benhamouda F (2004) Coastal uplift and thrust faulting associated with the Mw=6.8 Zemmouri (Algeria) earthquake of 21 May, 2003. Geophysical Research Letters 31 (L19605, doi:10.1029/2004GL020466).

Pestana JM, Nadim F (2000) Nonlinear site response analysis of submerged slopes. Technical Report UCB/GT/2000-04, Department of Civil and Environmental Engineering.

Pestana JM, Biscontin G, Nadim F, Andersen K (2000) Modeling cyclic behavior of lightly overconsolidated clays in simple shear. Soil Dynamics and Earthquake Engineering 19(7): 501519.

Piper DJW, Shor AN, Farre JA, O'Connell S, Jacobi R (1985) Sediment slides around the epicentre of the 1929 Great Banks earthquake. Geology 13: 538-541.

Piper DJW, Cochonat P, Morrison ML (1999) The sequence of events around the epicenter of the 1929 Great Banks earthquake: initiation of debris flow and turbidity current inferred from sidescan sonar. Sedimentology 46: 79-97.

Reimer PJ, Bard EMB, Bayliss A, Beck JW, Bertrand C, Blackwell PG, Buck CE, Burr G, Cutler KB, Damon PE, Edwards RL, Fairbanks RG, Friedrich M, Guilderson TP, et al. (2004). "C14." Radiocarbon 46: 1029-1058.

Robertson PK, Fear CE (1995) Liquefaction and sands and its evaluation. Keynote lecture. In: IS Tokyo '95, Proceedings of the 1st International Conference on Erathquake Geotechnical Engineering; K. Ishihara (Ed.), Amsterdam.

Savoye B (2005) Maradja 2 cruise report, IFREMER.

Seed HB (1979) Soil liquefaction and cyclic mobility evaluation for level ground during earthquakes. Journal of the Geotechnical Engineering Division, ASCE 105(GT2): 201-255.

Seed HB, Idriss IM (1971) Simplified procedure for evaluating soil liquefaction potential. Journal of the Soil Mechanics and Foundations Division, ASCE 97(SM9): 1249-1273. 
Seed RB, Cetin KO, Moss RES, Kammerer AM, Wu J, Pestana JM, Riemer MF (2001) Recent Advances in Soil Liquefaction Engineering, and Seismic Site Response Evaluation. Paper. I.20; University of California, Berkeley, California.

Semmane F, Campillo M, Cotton F (2005) Fault location and source process of the Boumerdès, Algeria, earthquake inferred from geodetic and strong motion data. Geophysical Research Letters 32(L01305, doi:10.1029/2004GL021268).

Sultan N (2004) PRISMA cruise report, IFREMER.

Sultan N, Cochonat P, Cayocca F, Bourillet JF, Colliat JL (2004) Analysis of submarine slumping in the Gabon continental slope, In High-Resolution Geophysical Studies of Continental Margins Geohazards. Special issue of AAPG Bulletin 88(6): 781-799.

Sultan N, Gaudin M, Berné S, Canals M, Urgeles R, Lafuerza S (2007) Analysis of slope failures in submarine canyon heads: an example from the Gulf of Lions. Journal of Geophysical Research (doi: 10.1029/2005JF000408).

Yang Z, Lu J, Elgamal A (2004) A web-based platform for computer simulation of seismic ground response. Advances in Engineering Software 35: 249-259.

Youd TL, Idriss IM, Andrus RD, Arango I, Castro G, Christian JT, Dobry R, Finn WDL, Harder LF, Hynes ME, Ishihara K, Koester JP, Liao SSC, Marcuson III WF, Martin GR, Mitchell JK, Moriwaki Y, Power MS, Robertson PK, Seed RB, Stokoe II KH (2001) Liquefaction resistance of soils: summary report from the 1996 NCEER and 1998 NCEER/NSF workshop on evaluation of liquefaction resistance of soils. Journal of Geotechnical and Geoenvironmental Engineering, ASCE, October: 817-833.

Yoshimi Y, Richart FE, Prakash S, Balkan DD, Ilyichev YL (1977) Soil dynamics and its application to foundation engineering. In: Proceedings of the 9th International Conference of Soil Mechanics and Foundation Engineering, Tokyo 2: 605-650. 
Table 1: Results of radiocarbon dating on sediment samples from cores MD04-2799 and KMDJ16. A correction of 400 years is applied for the ocean reservoir age effect.

Table 2: Results from oedometer tests on samples from cores MD04-2799 and KMDJ-16. Most results correspond to underconsolidated sediment.

Table 3: Results from the cyclic triaxial tests carried out on samples from sediment core MD042799.

Table 4: Geotechnical properties of each of the 18 layers used for CYCLIC 1D, where $\gamma$ is the unit weight, $\mathrm{Su}$ is the undrained shear strength, $\varphi^{\prime}$ is the internal friction angle and Vs is the shear wave velocity. Permeability is determined from oedometer tests. Asterisk $(*)$ refers to values estimated from lithology.

Table 5: Geotechnical properties of each of the 9 layers used for SAMU 3D model, where $\gamma$ is the unit weight, $\mathrm{Su}$ is the undrained shear strength and $\varphi^{\prime}$ is the internal friction angle. The horizontal acceleration is calculated using CYCLIC 1D model for an earthquake of a PGA $=0.1 \mathrm{~g}$. Asterisk (*) refers to values estimated from lithology. 
Figure 1: Shaded relief image of the Algiers margin showing the seafloor main features. The shaded image in grey has been produced from swath bathymetry data. Onland geology illustrates the main units of the Maghrebian chain. Box shows the location of the study area. B1-B5: Base of the slope breaks. S1-S3: Distal margin slope breaks. D1-D4: Basins. Black star: epicentre of the 2003 Boumerdès earthquake.

Figure 2: (a) Shaded relief image showing mass-wasting features on the S1 area. (b) Slope gradient map of the S1 area. (c) Down dip section across the westernmost slope destabilization area showing a slide headscarp and slide deposits down slope and (d) Along strike cross section showing the sidewalls and slide deposits of the same slope destabilization area. Location of sections (c) and (d) is shown in (b). SAR 10 track, location of sediment cores MD04-2799 and KMDJ-16 and location of Figures 3 and 4 are shown in figures (a) and (b). See location of (a) and (b) in Figure 1. Location of Figure 14a is also shown.

Figure 3: (a) SAR 10 interpreted sonar image and (b) $3.5 \mathrm{kHz}$ parallel seismic reflection profile showing a collapsed area at the top of the S1 escarpment. Vertical scale in (b) is in meters. Location in Figures $2 \mathrm{a}$ and $2 \mathrm{~b}$.

Figure 4: (a) SAR 10 interpreted sonar image and (b) $3.5 \mathrm{kHz}$ parallel seismic reflection profile showing the presence of scarps and slided sediments on the lower part of the S1 escarpment. Vertical scale in (b) is in meters. Location in Figures $2 \mathrm{a}$ and $2 \mathrm{~b}$.

Figure 5: Logs of KMDJ-16 sediment core. (a) Lithology log. (b) Grain size distribution (\%). (c) Unit weight $\gamma(\mathrm{kN} / \mathrm{m} 3)$. (d) Compression wave velocities $\mathrm{Vp}(\mathrm{m} / \mathrm{s})$. (e) Undrained shear strength $\mathrm{Su}(\mathrm{kPa})$. White rectangles in the lithology log correspond to subsections extracted for laboratory geotechnical tests.

Figure 6: X-ray radiographs of specific intervals within sediment core KMDJ-16. (a) Sand migration into the silty clay matrix (4.25-4.49 mbsf). (b) Discontinuous sand bed (6.75-6.85 mbsf). (c) Discontinuous sand bed and plastic deformation (8.50-8.58 mbsf). (d) Continuous sand beds showing parallel laminas (7.35-7.62 mbsf). (e) Grain-size distribution cumulative curve (\%) showing the massive structure of the sand beds (7.35-7.62 mbsf).

Figure 7: Logs of MD04-2799 sediment core. (a) Lithology log. (b) Grain size distribution (\%). (c) Unit weight $\gamma(\mathrm{kN} / \mathrm{m} 3)$. (d) Compression wave velocities $V p(\mathrm{~m} / \mathrm{s})$. (e) Undrained shear strength $S u$ $(\mathrm{kPa})$. (f) X-ray image between 15.24 and $15.28 \mathrm{mbsf}$ showing the deformation of a sand bed. White rectangles in the lithology log correspond to subsections extracted for laboratory geotechnical tests.

Figure 8: Results of the oedometer tests carried out on sediment cores MD04-2799 and KMDJ-16. (a) Results from the upper part of the two cores (samples at 2.45 and $3.95 \mathrm{~m}$ core depth for MD042799; and at 0.83, 1.85 and $2.85 \mathrm{~m}$ core depth KMDJ-16). (b) Results from the lower part of the core MD04-2799 (all samples beneath $4.5 \mathrm{~m}$ core depth).

Figure 9: Over Consolidation Ratio (OCR) calculated from oedometer tests carried out on both sediment cores, KMDJ-16 and MD04-2799, showing that the sediment is usually underconsolidated.

Figure 10: Results from undrained triaxial cyclic tests. (a) Test VI-1 showing that failure occurs after 15 cycles with an axial strain greater than $10 \%$. (b) Test IX-2 showing the liquefaction after 5 cycles $\left(\Delta \mathrm{u} / \sigma_{3 \mathrm{c}}=0.95\right)$. 
Figure 11: (a) Diagram of the cyclic resistance ratio CRR a function of the number of cycles necessary to reach liquefaction after cyclic tests carried out on sediment subsamples from core MD04-2799. (b) Evaluation of the liquefaction potential based on the empirical method (Seed and Idriss, 1971).

Figure 12: Grain size logs and examples of deformations during cyclic triaxial tests on subsections from sediment core MD04-2799 (see Table 3). The deformation of both samples is characterized by a decrease of the initial deviatoric stress $\left(\sigma_{\mathrm{d} \text {,cyc }} / 2 \sigma^{\prime}{ }_{3}\right)$, probably corresponding to a localized liquefaction of the sandy layer, which was not recorded by the pore pressure sensors since they are only connected to the top and the bottom of the sample. (a) Grain size log of core subsection V-3. (b) Photograph of core subsection V-3 after cyclic triaxial test. (c) Grain size log of core subsection VI-1. (b) Photograph of core subsection VI-1 after cyclic triaxial test.

Figure 13: Results of the numerical simulation using CYCLIC 1D (see main text). (a) Horizontal acceleration $\left(\mathrm{m} / \mathrm{s}^{2}\right)$. (b) Excess pore pressure $(\mathrm{kPa})$. (c) Effective confinement stress $(\mathrm{kPa})$ calculated for a PGA of $0.1 \mathrm{~g}$ and $0.2 \mathrm{~g}$.

Figure 14: Results from the SAMU 3D simulation showing the most critical failure surfaces predicted for the subarea close to core MD04-2799 within the larger study area (see location in Figures 1 and 2). (a) Detailed bathymetric map of the subarea where SAMU 3D was applied, which is nearby landslides seafloor. (b) Critical failure surfaces under static loading (red) and under cyclic loading (blue).

Figure 15: FOS vs. number of calculation showing the convergence of the model and the minimum FOS. (a) Under static loading and undrained conditions (FOS = 1.45). (b) Under static loading and drained conditions (FOS $=5.5)$. (c) Under cyclic loading and undrained conditions $(\mathrm{FOS}=1.01)$.

Figure 16: Output results showing the shape of the most critical failure surface and the cross section along Neutral Line (NL) (see main text). (a) Critical failure surface under static untrained loading. (b) Cross section along NL under static loading. (c) Critical failure surface under cyclic loading. (d) Cross section along NL under cyclic loading (earthquake).

Figure 17: Sketches showing the depositional and tectonic setting of the Algerian continental margin. (a) Illustration of the most likely deposition setting during the last sea level low stand. (b) Drawing that shows how sea level rise and tectonics could combine leading to the cessation of the turbidite deposition at the location of the two cores analysed in this study. Black dots show the location of sediment cores MD04-2799 and KMDJ-16. 
Click here to download high resolution image

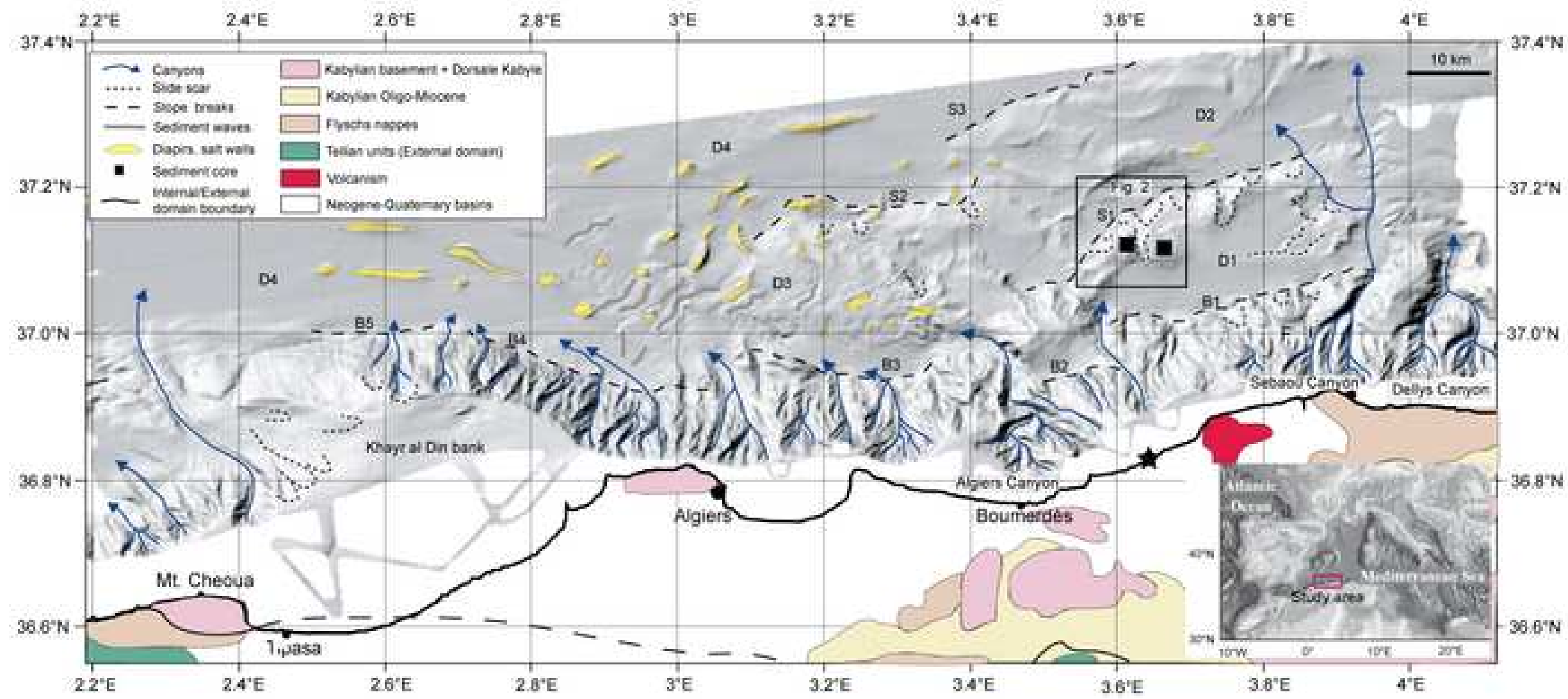




\section{Figure2}

Click here to download high resolution image

(a)

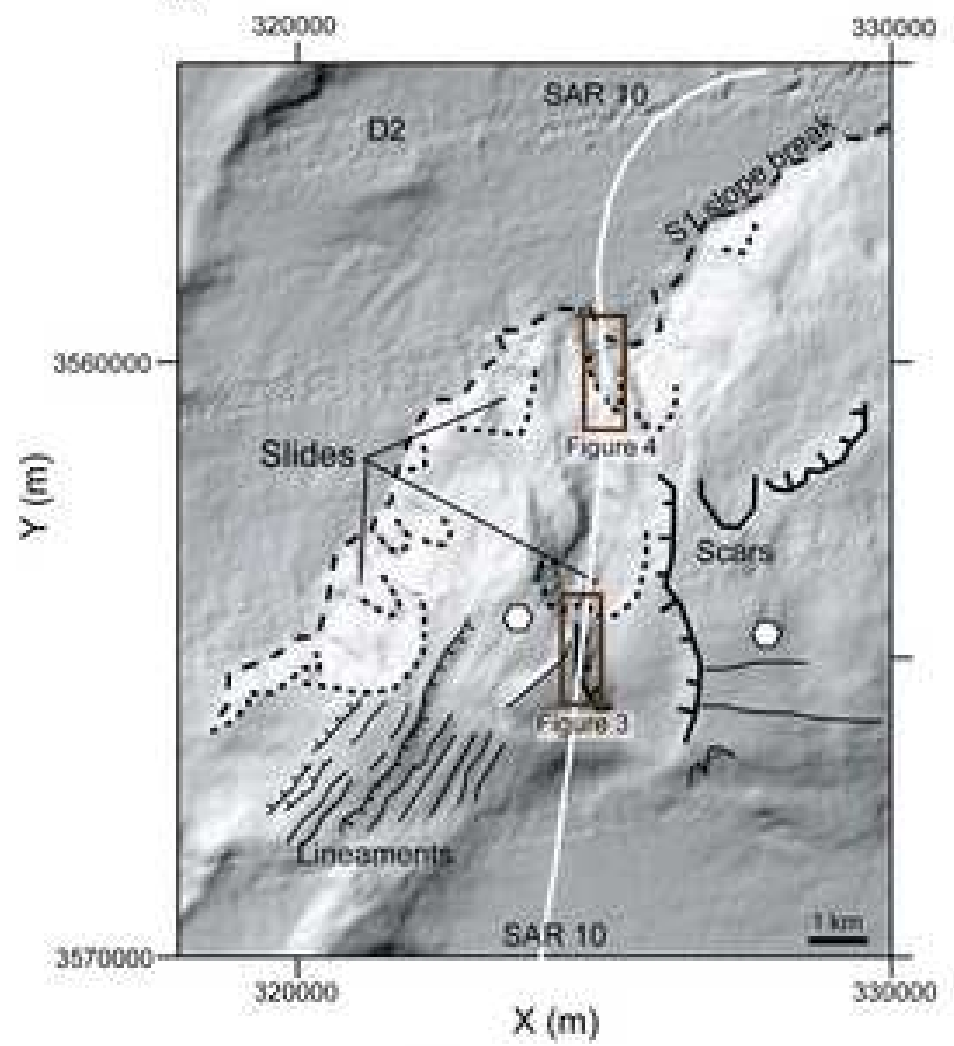

(b)

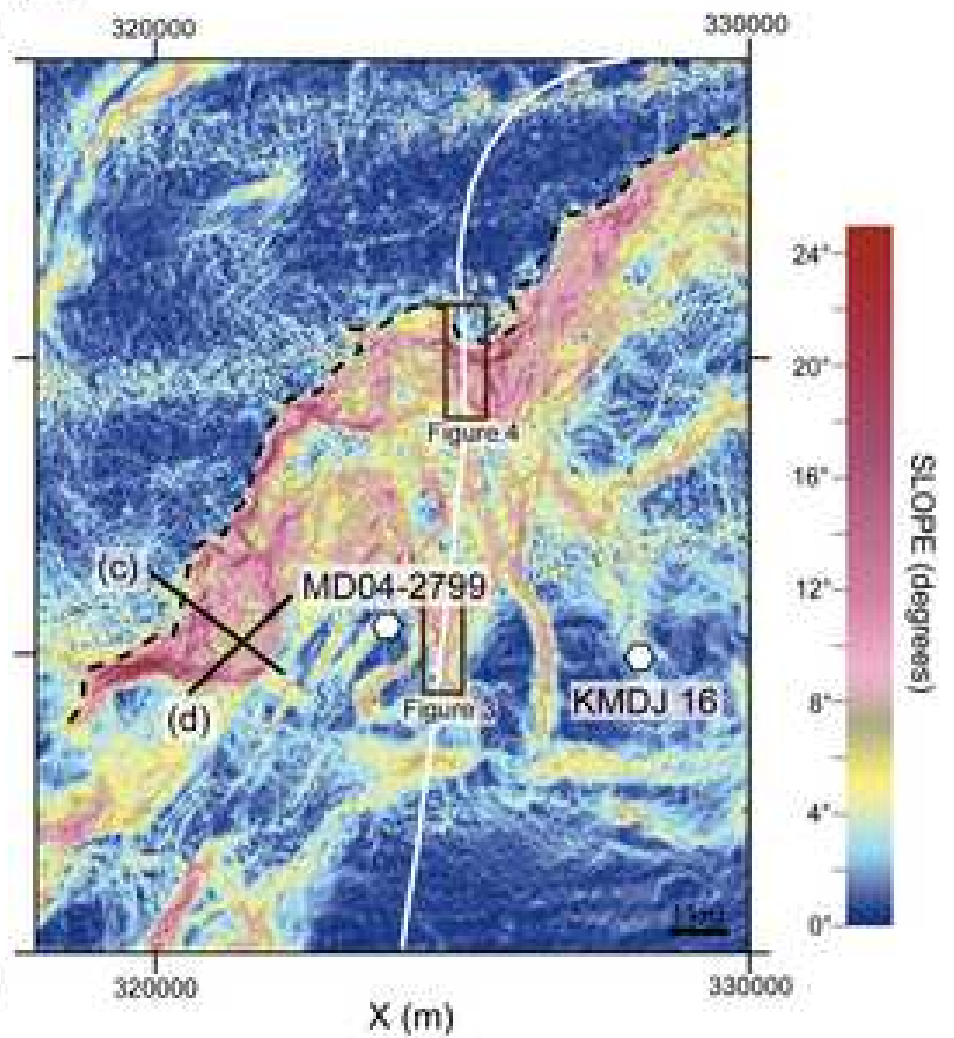

(c)

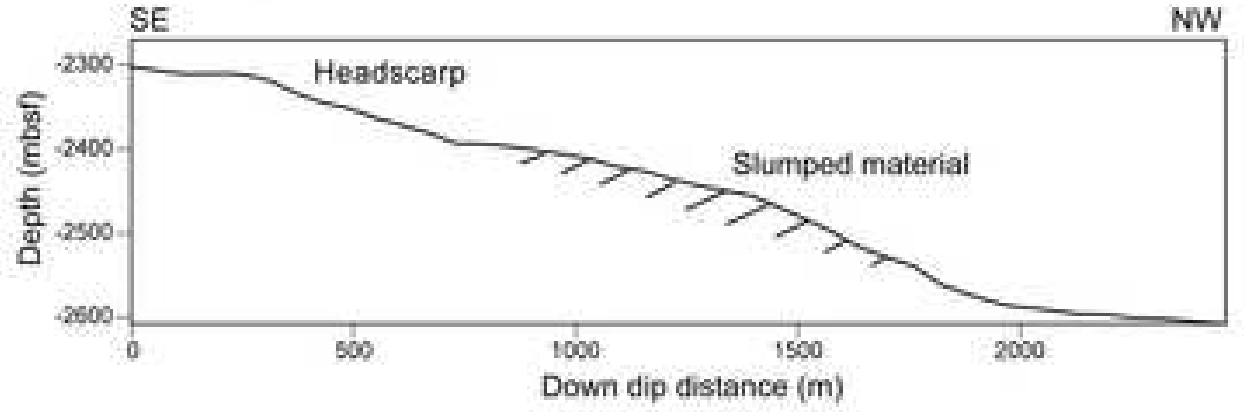

(d)

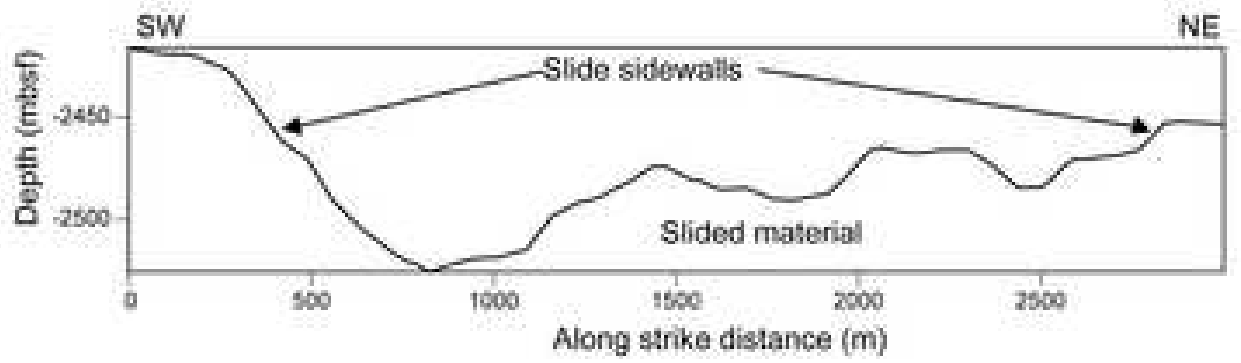




\section{Figure}

Click here to download high resolution image

(a) SW
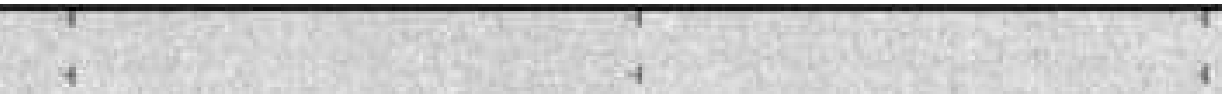

NE

(b)
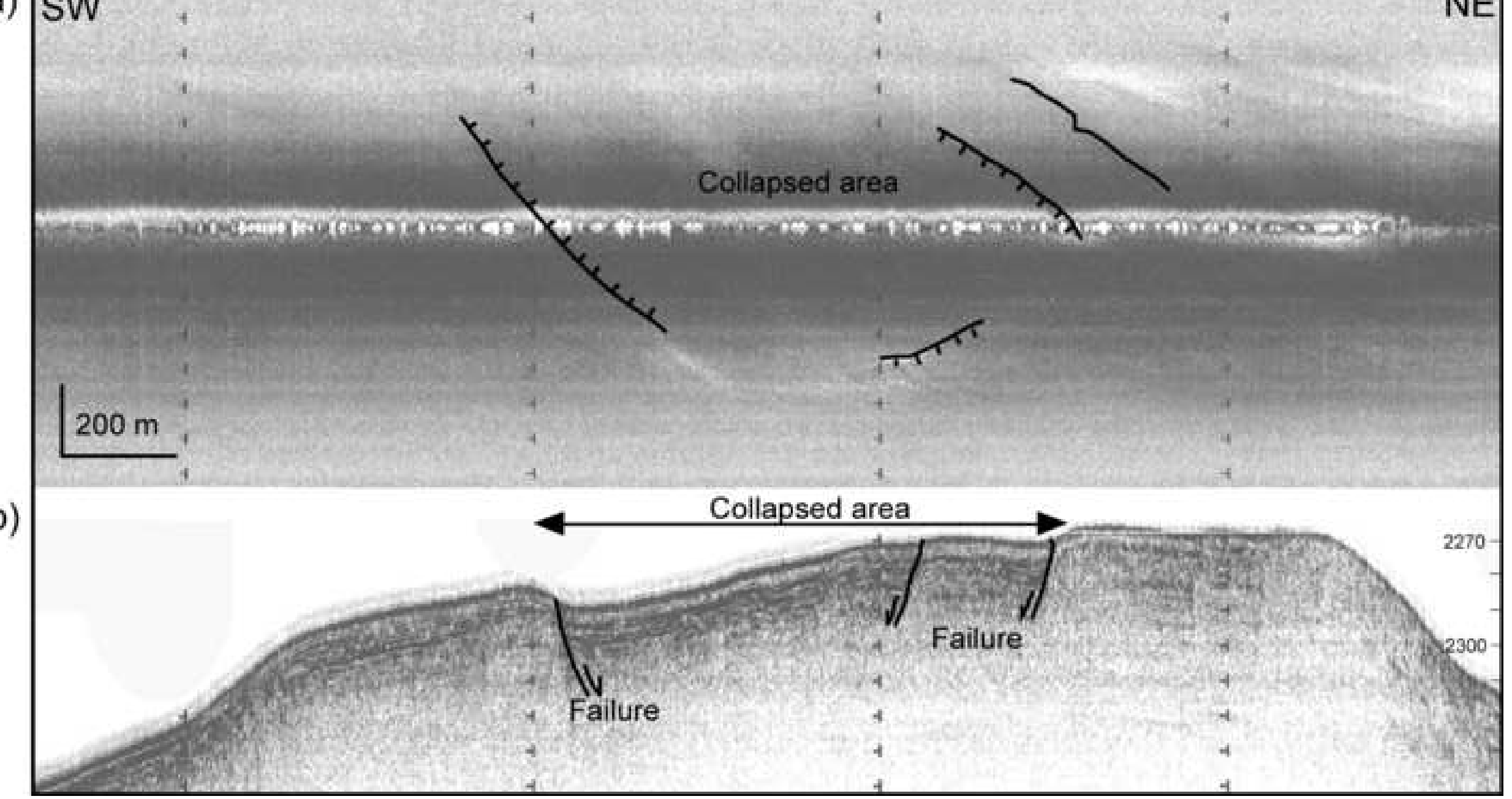
Click here to download high resolution image

(a) SW

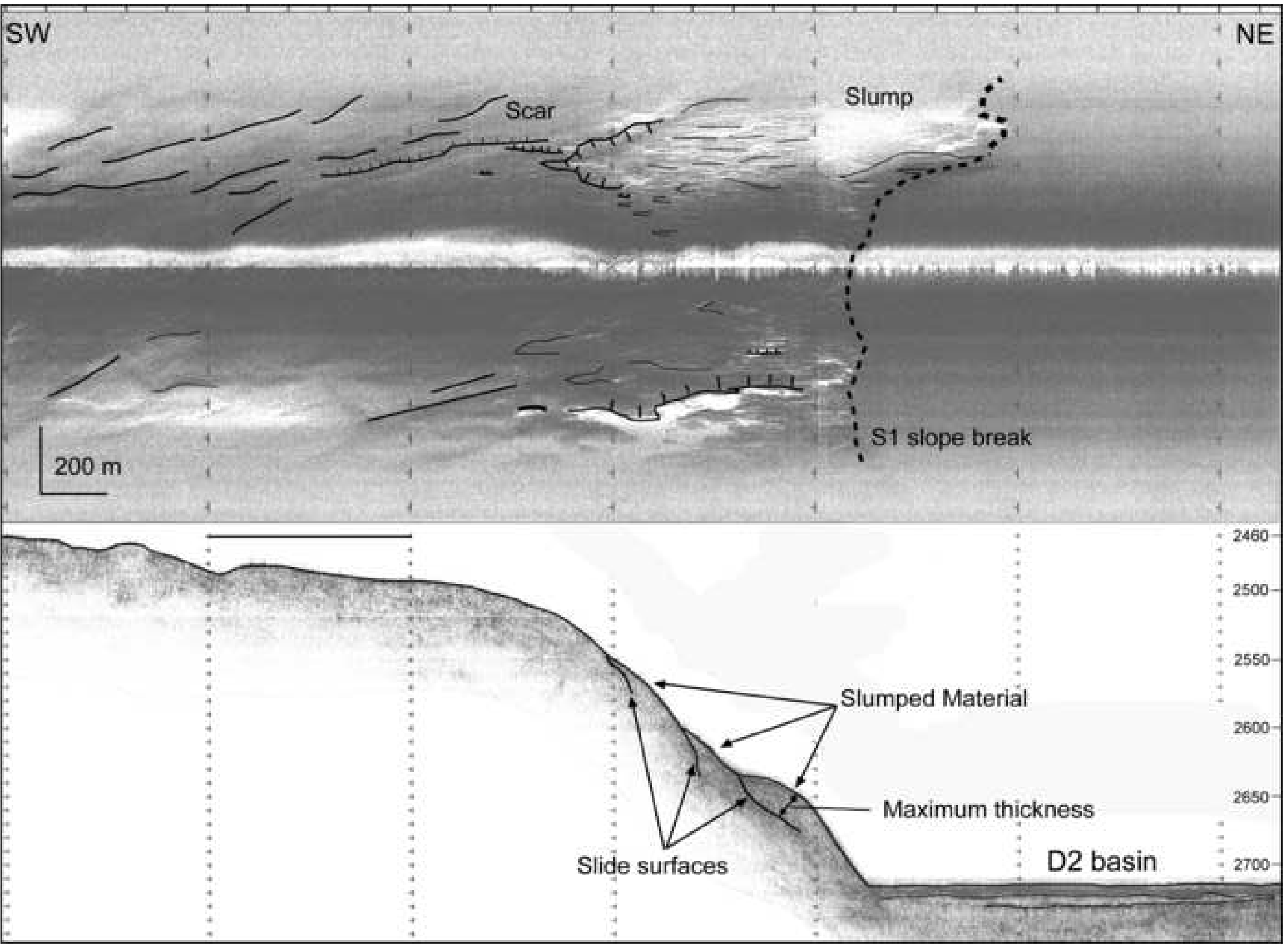

(b) 


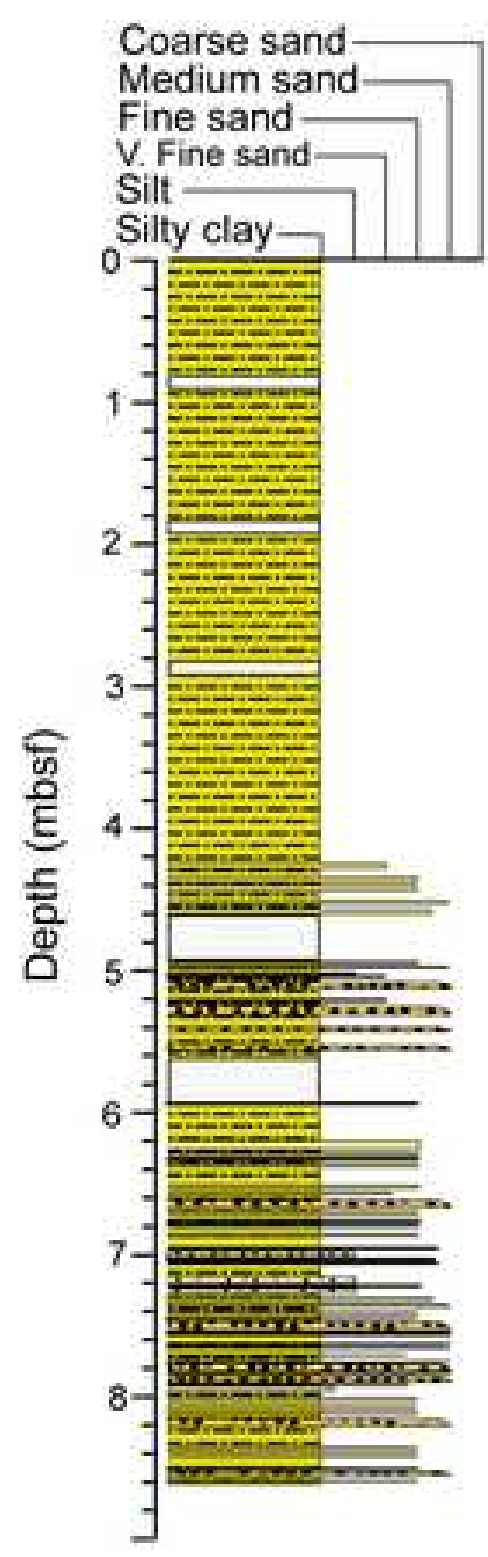

(a)
Grain size distribution (\%)

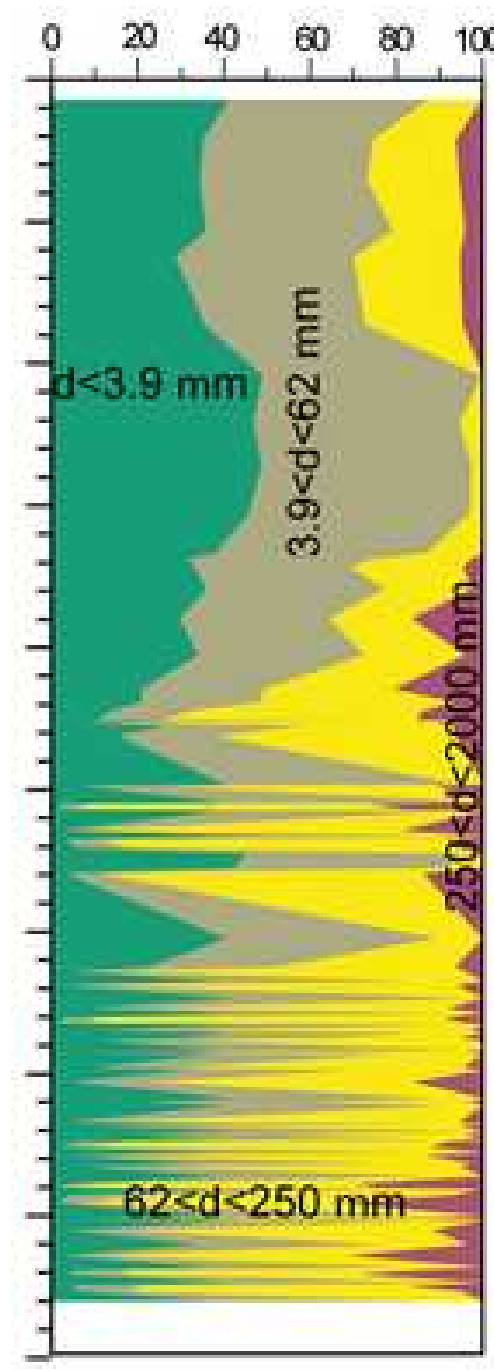

(b)
$\gamma\left(\mathrm{kN} / \mathrm{m}^{3}\right)$

$\mathrm{Vp}(\mathrm{m} / \mathrm{s})$

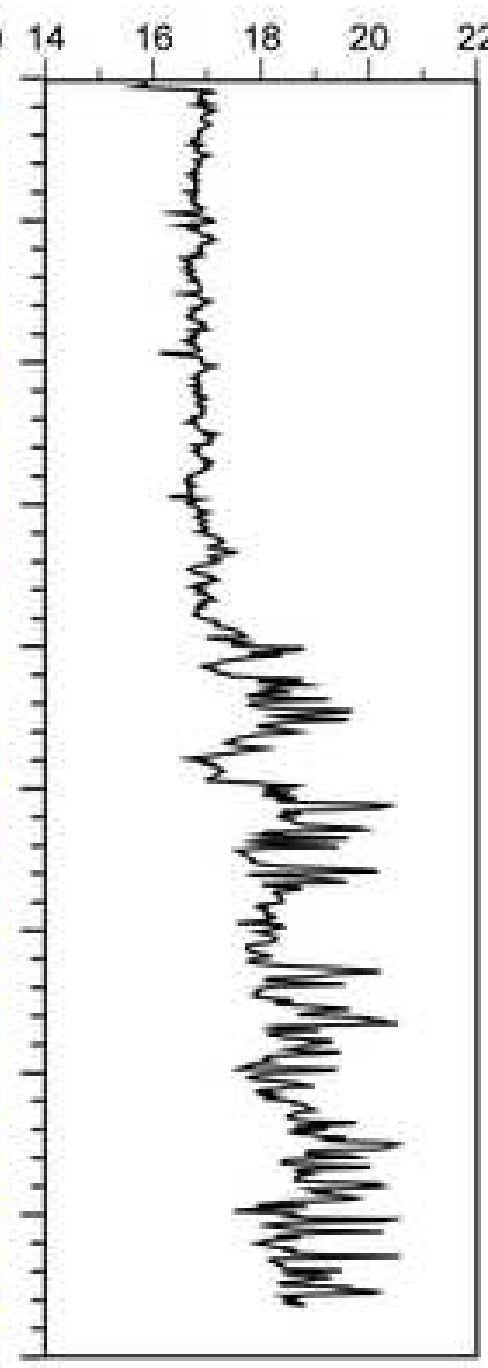

(c)

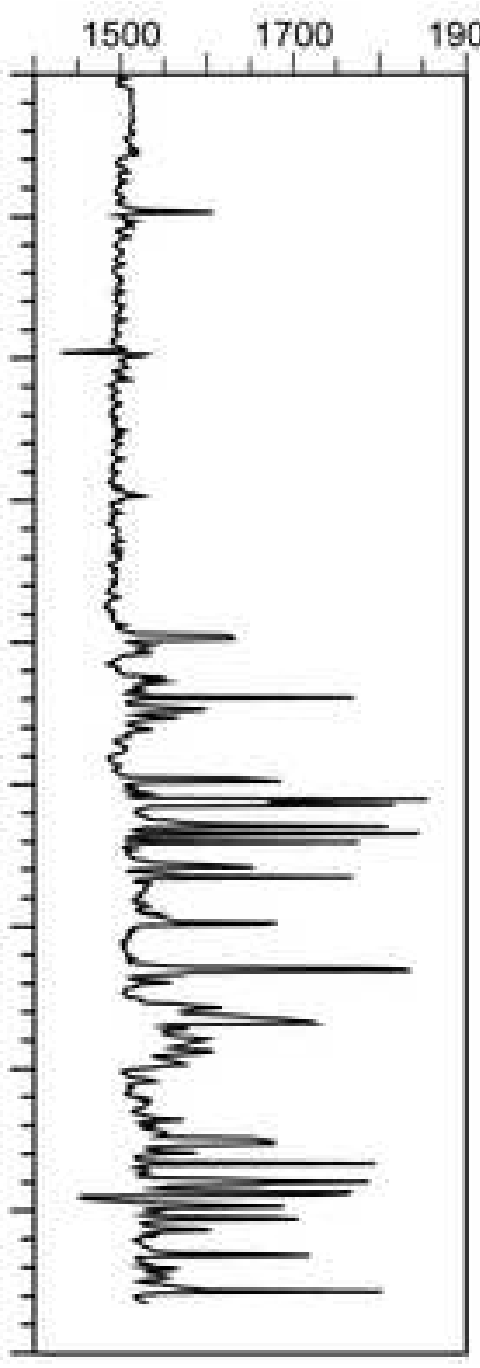

(d)
Su $(\mathrm{kPa})$

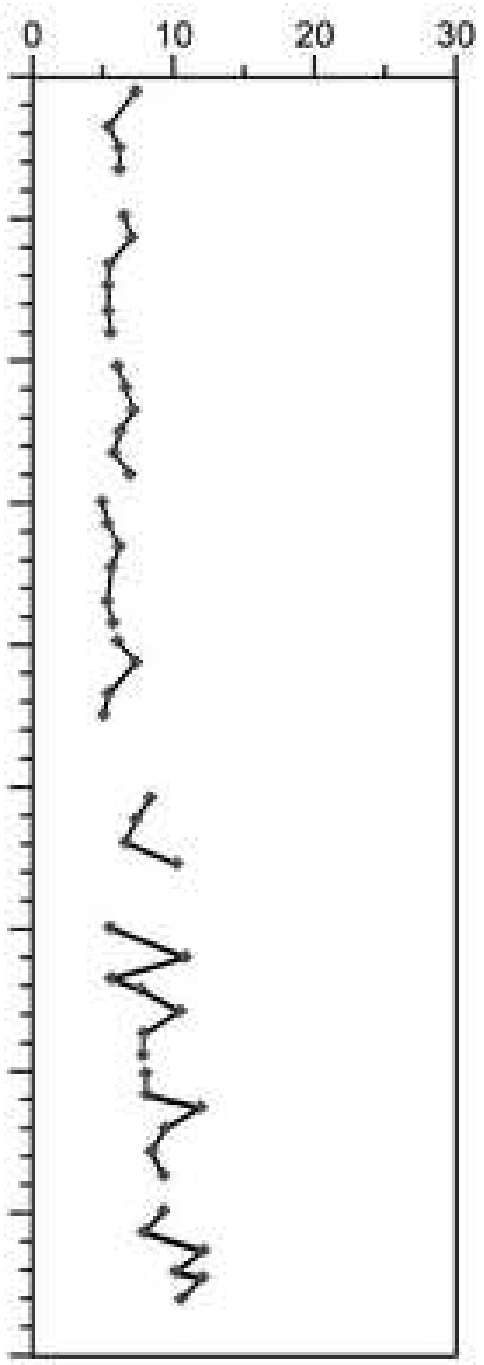

(e) 
(a)

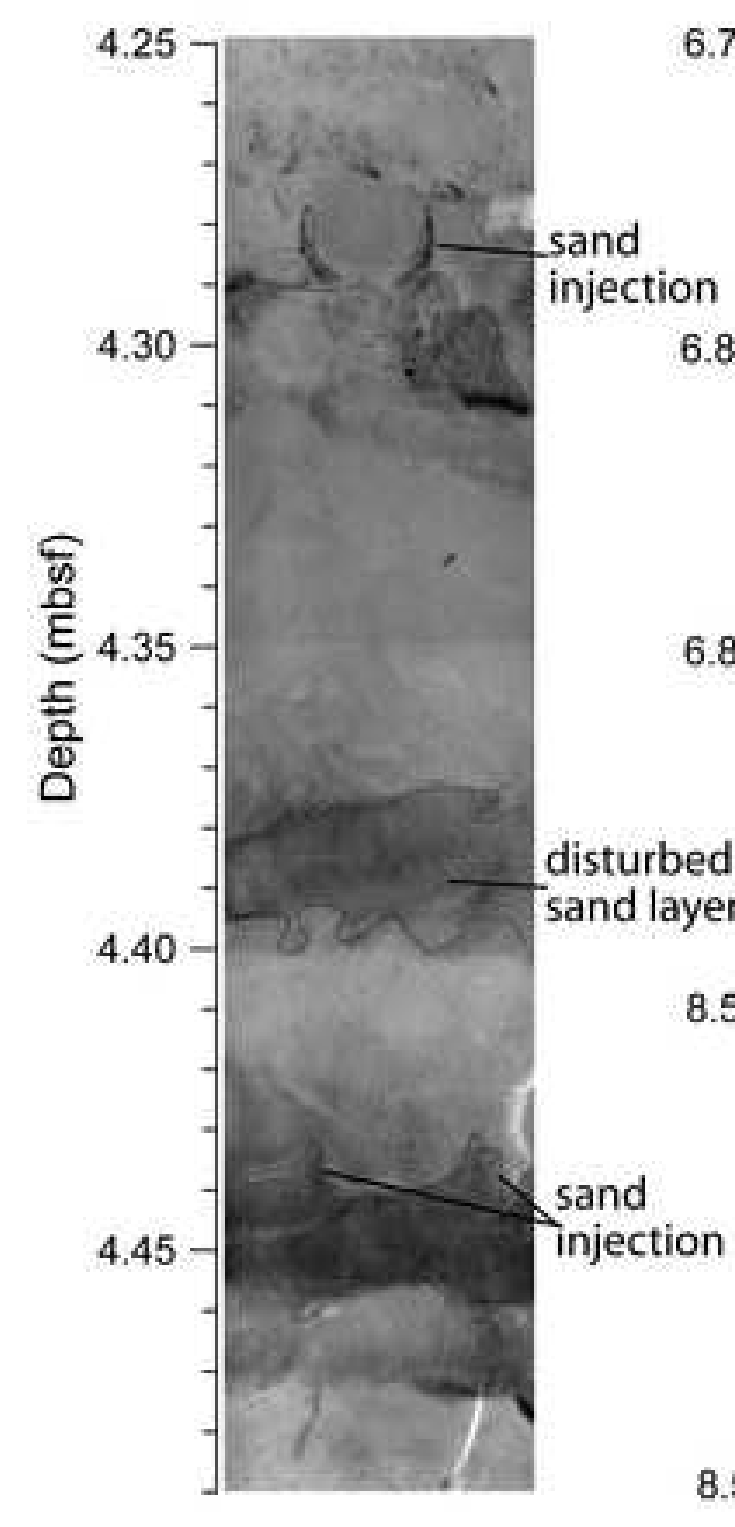

(b)

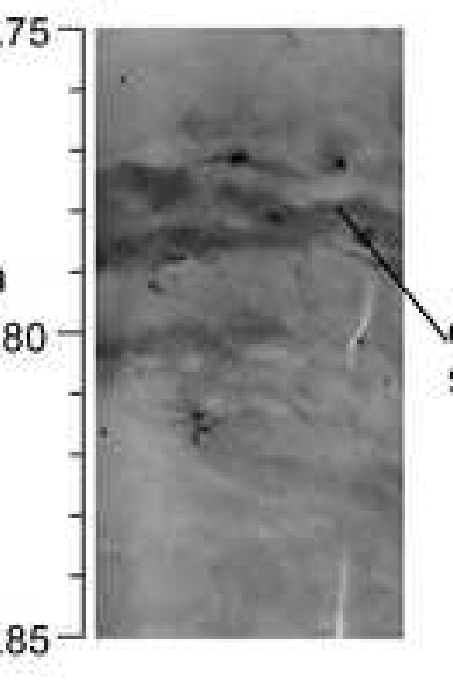

(c)

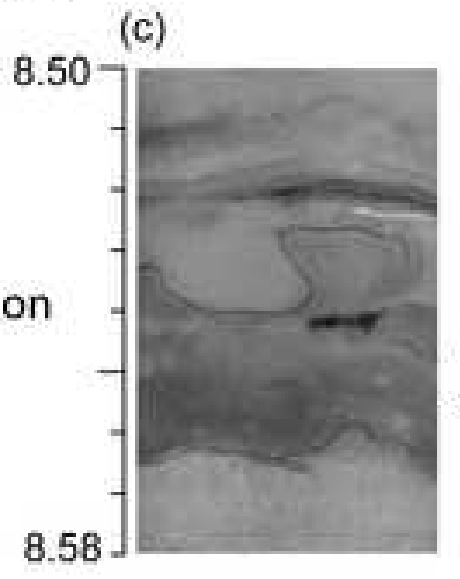

(d)

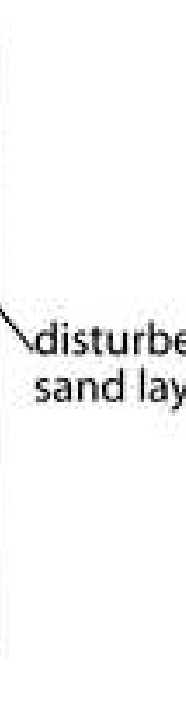

disturbed sand layer

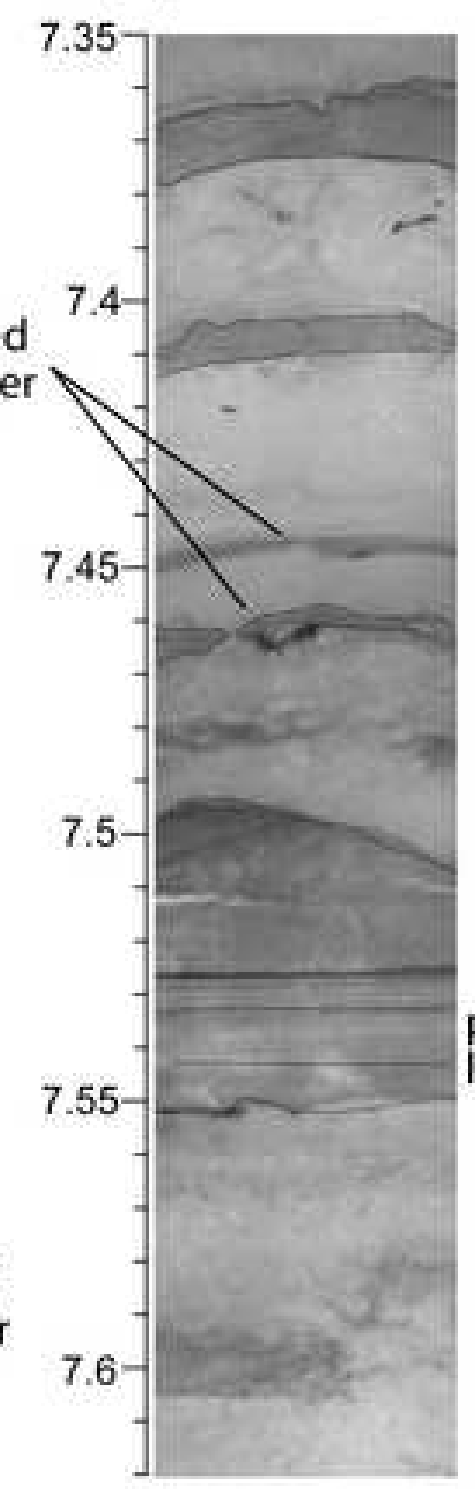

(e) Grain size distribution (\%)

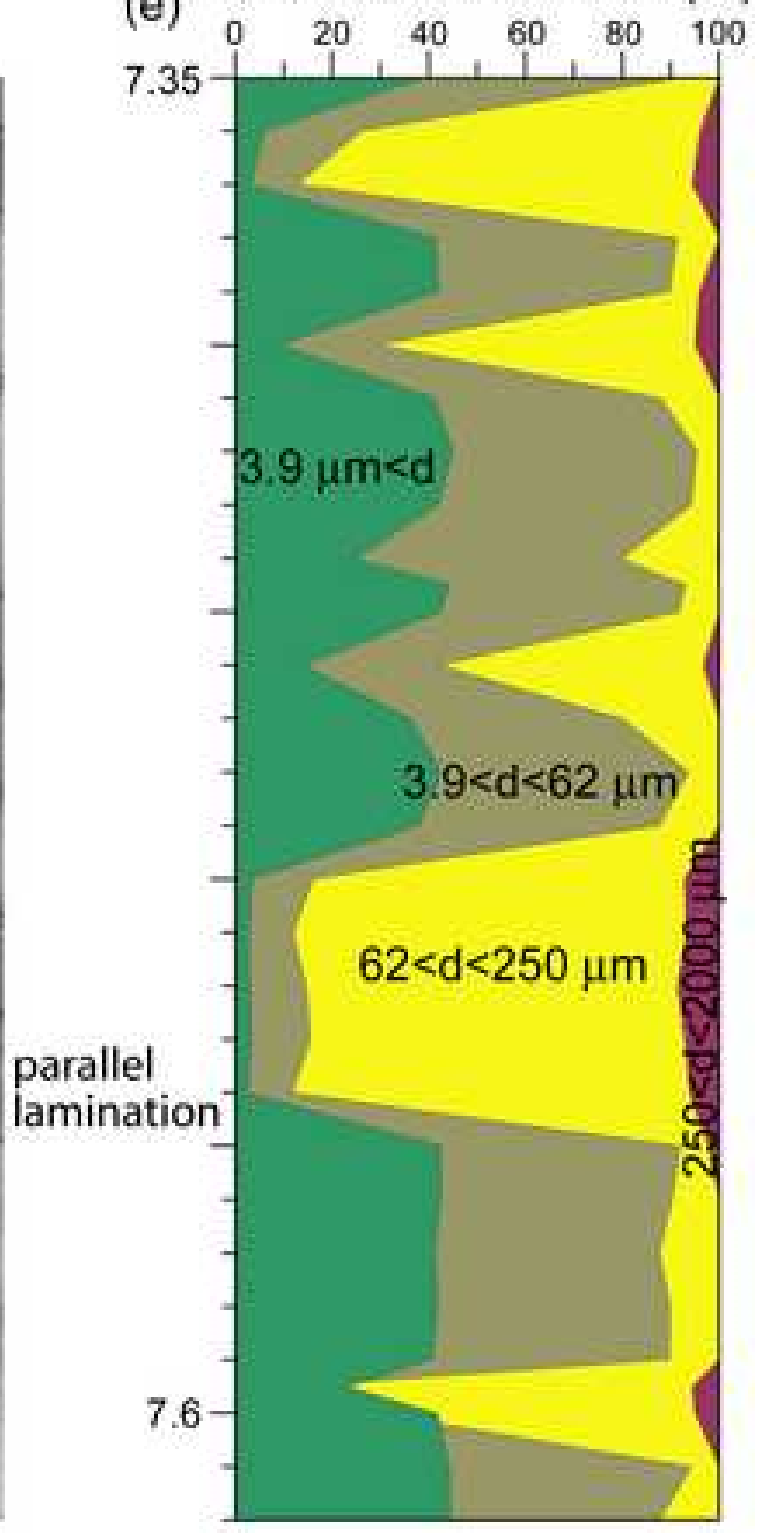




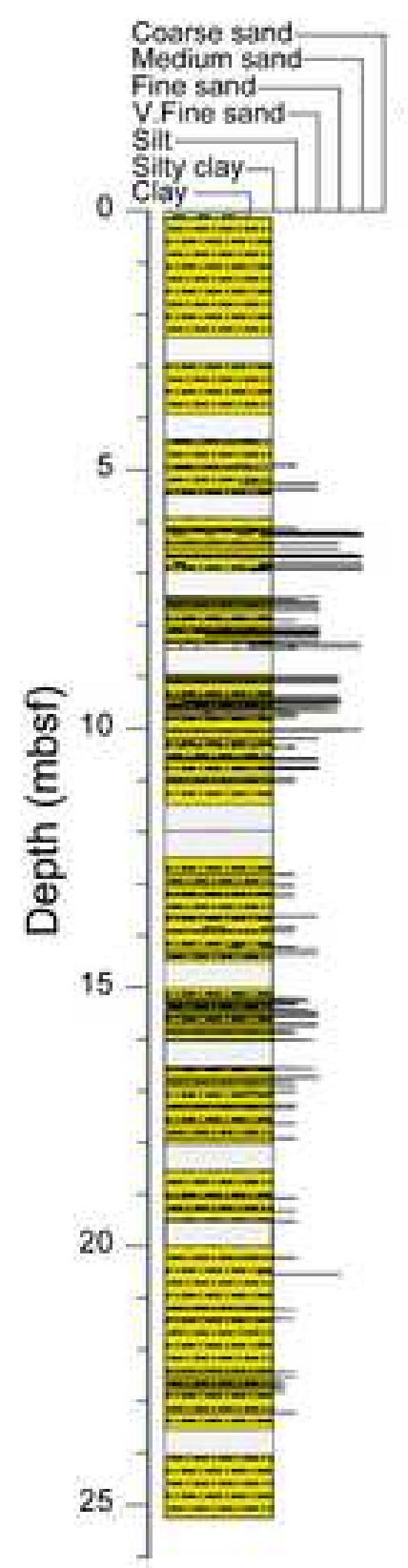

(a)
Grain size distribution (\%) $\quad \gamma\left(\mathrm{kN} / \mathrm{m}^{3}\right)$

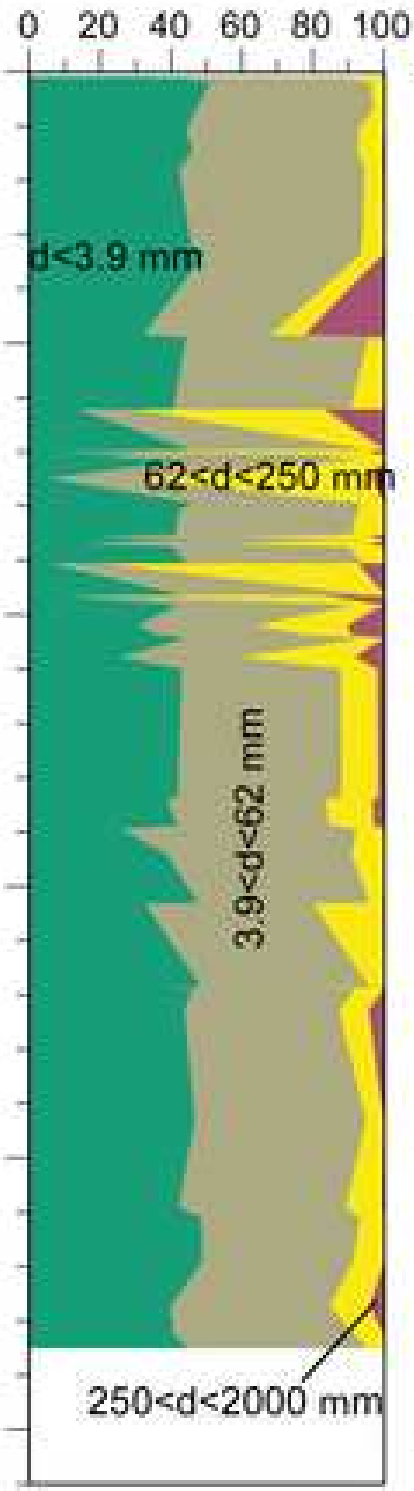

(b)

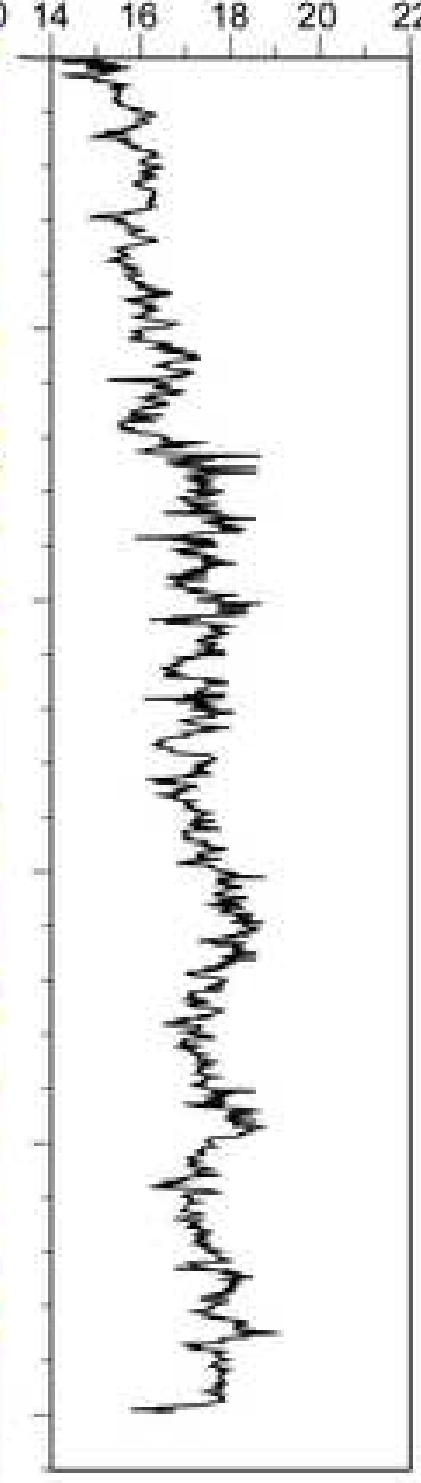

(c)

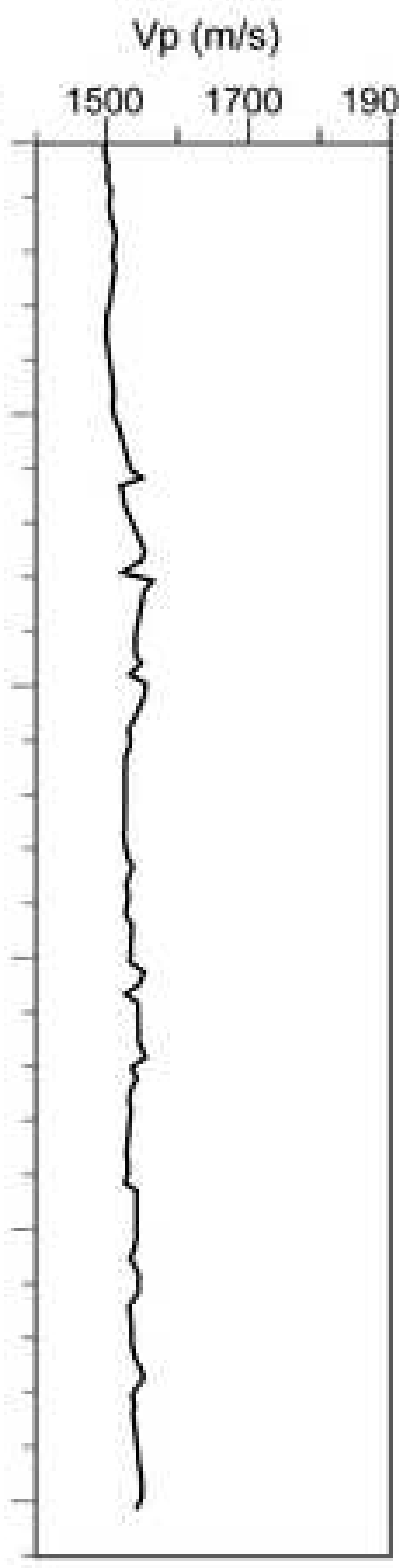

(d)
$\mathrm{Su}(\mathrm{kPa})$

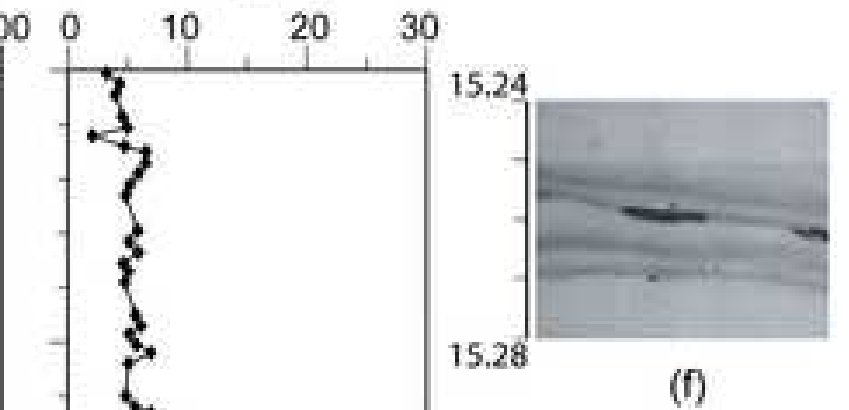

(f) 
(a)

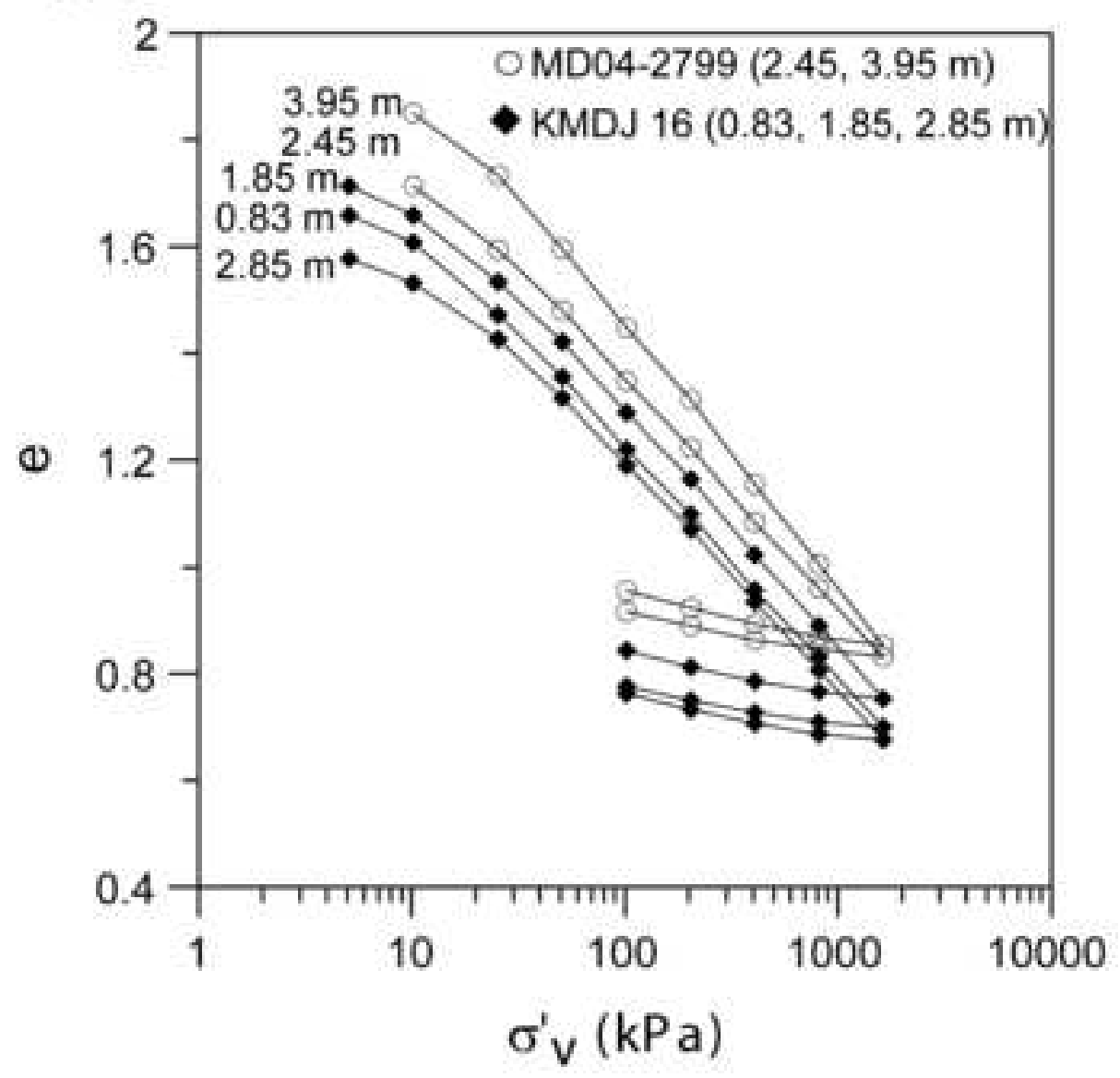

(b)

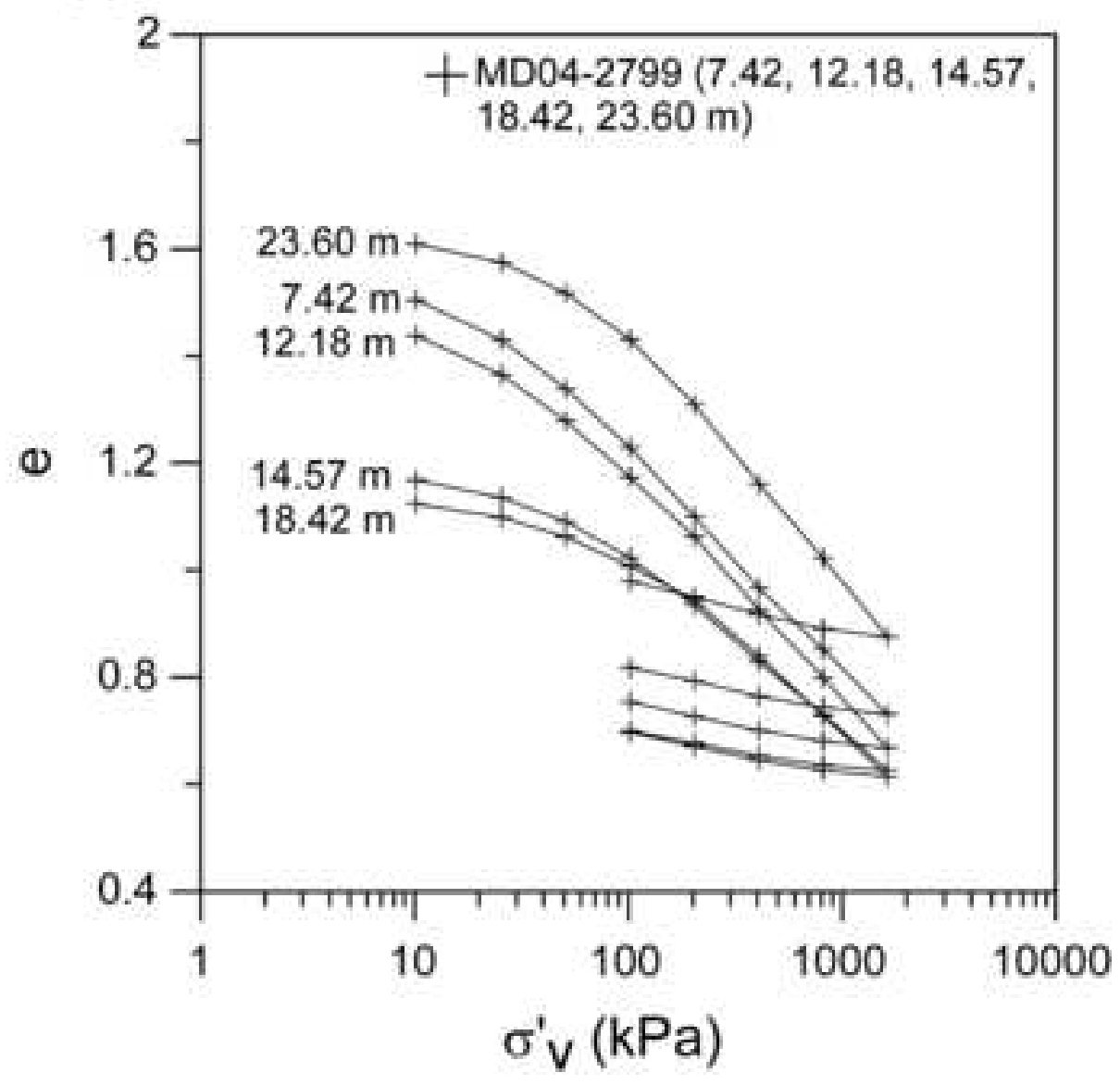


Figure9

Click here to download high resolution image

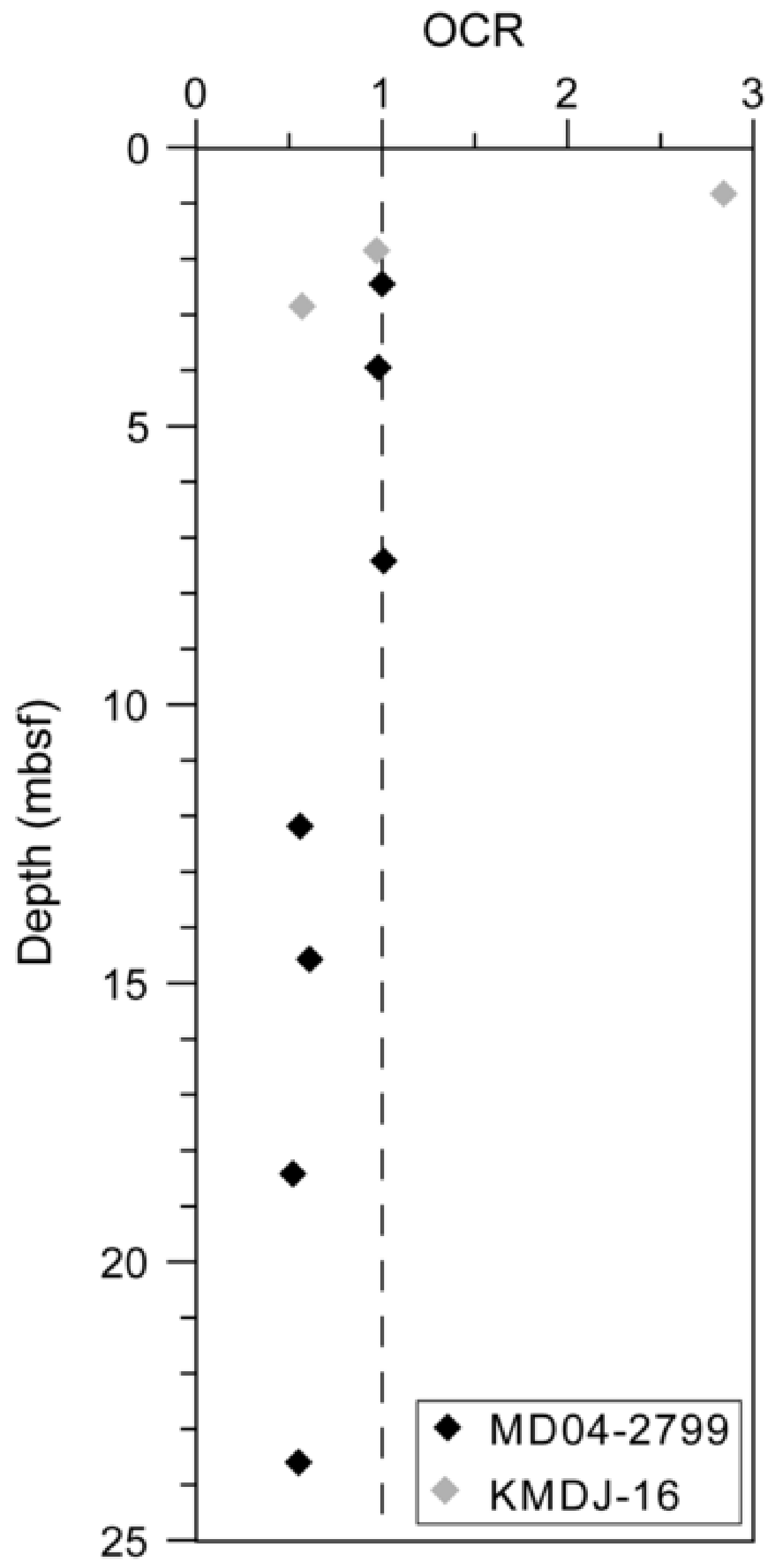


(a) test VI-1
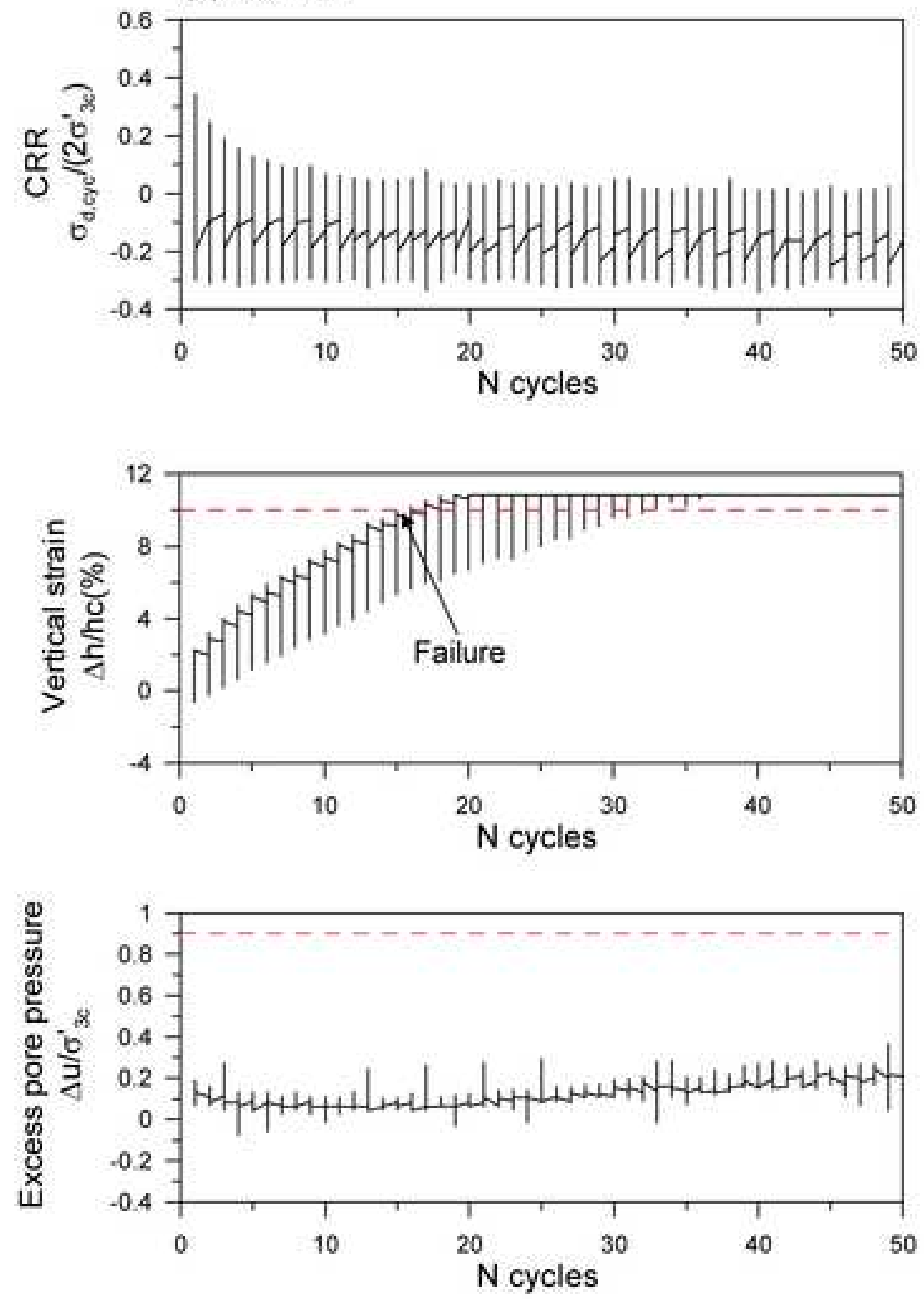

(b) test IX-2
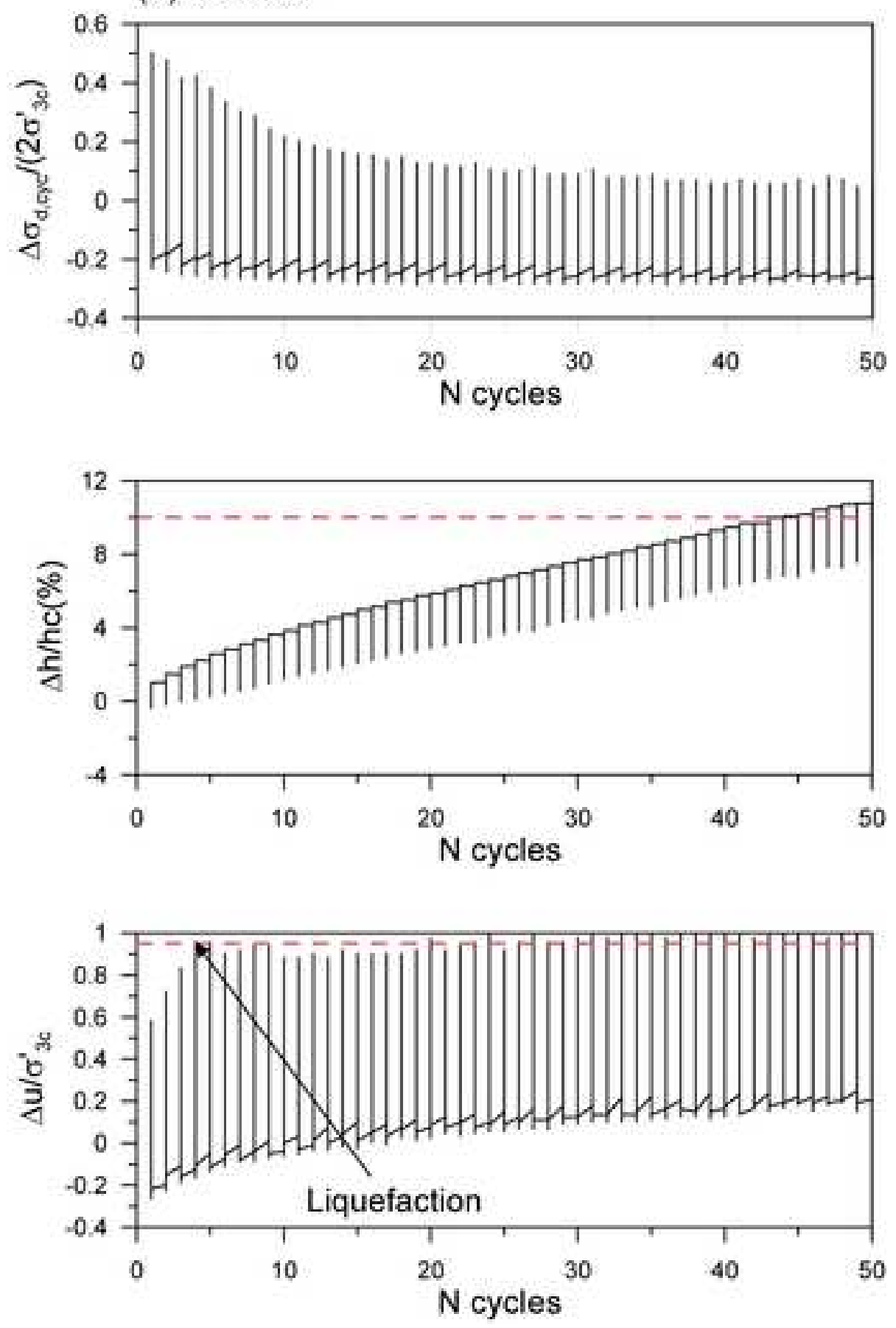
(a)

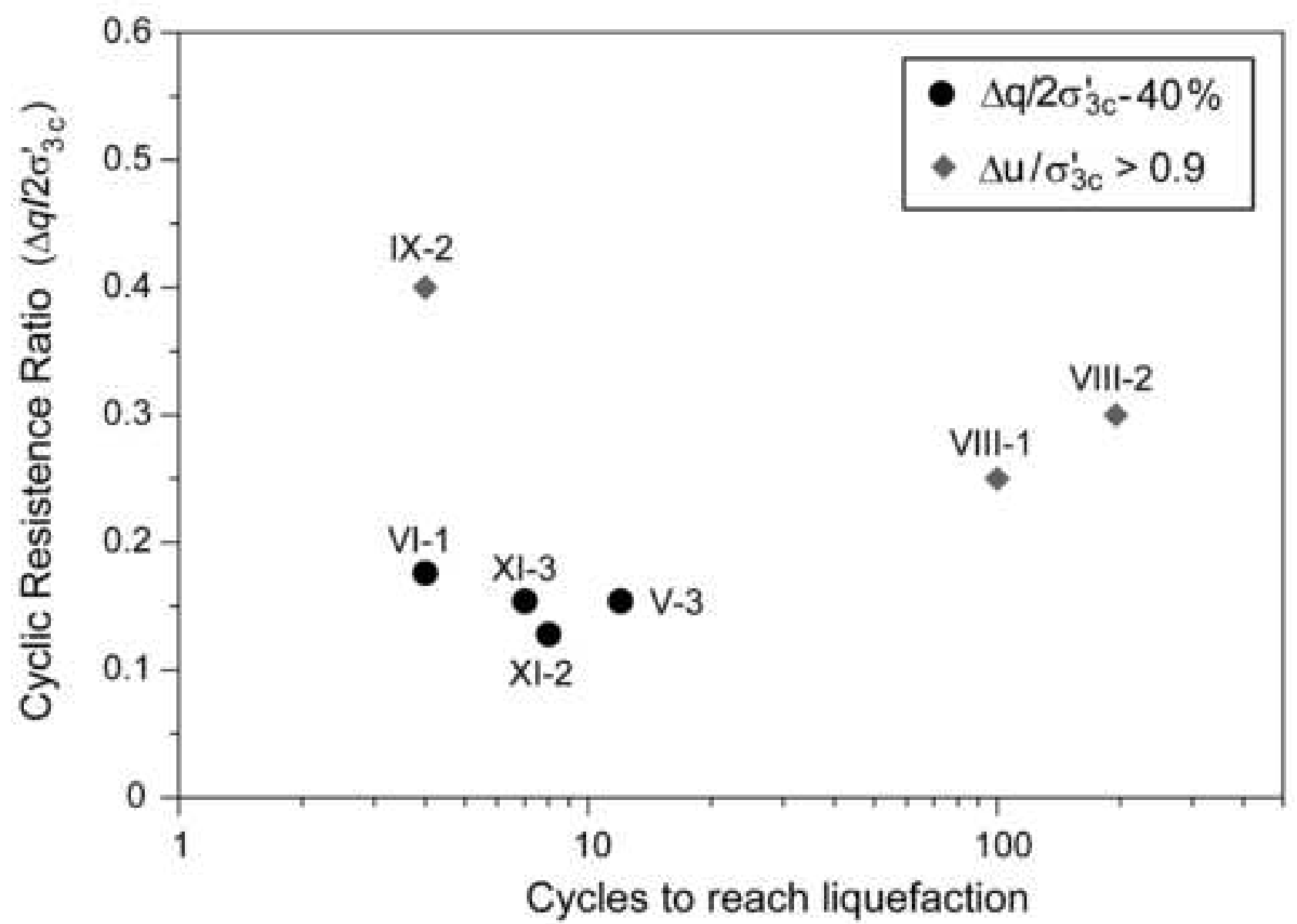

Cycles to reach liquefaction (b)

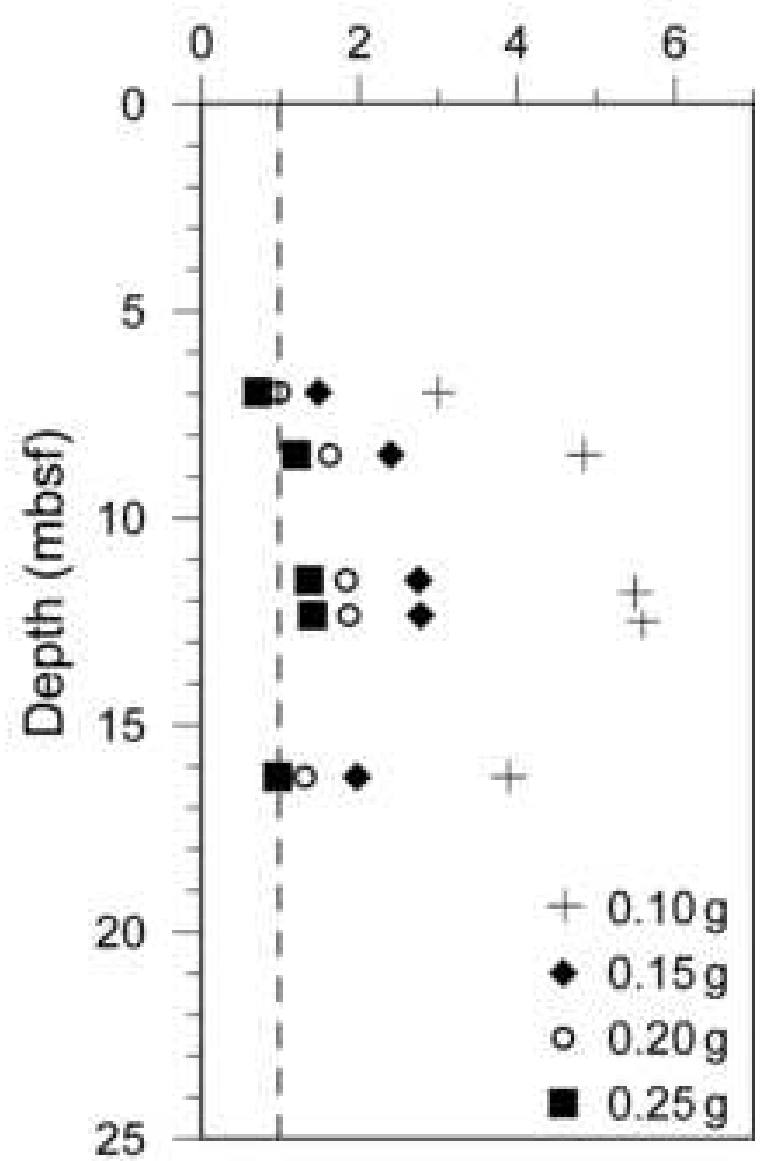




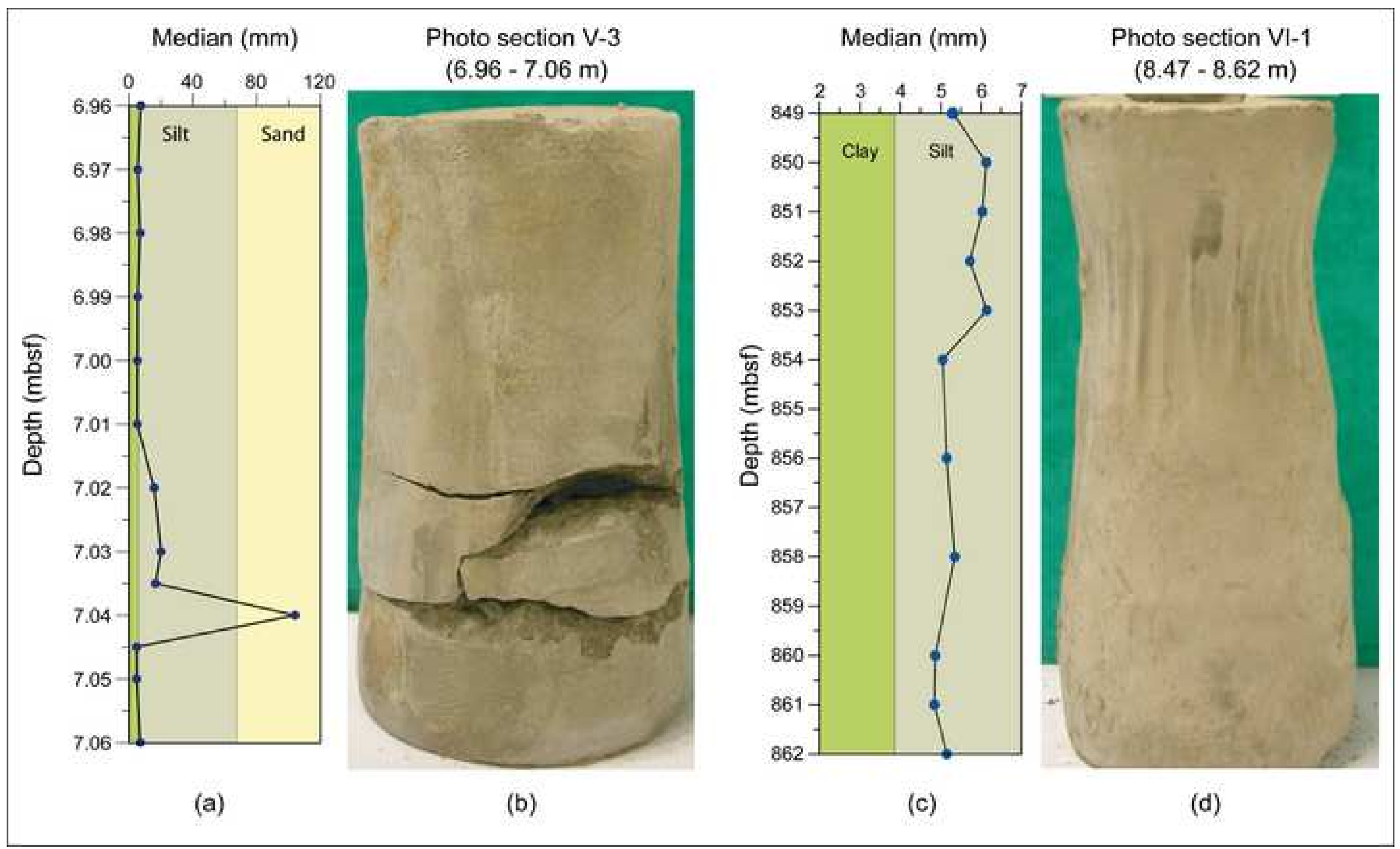




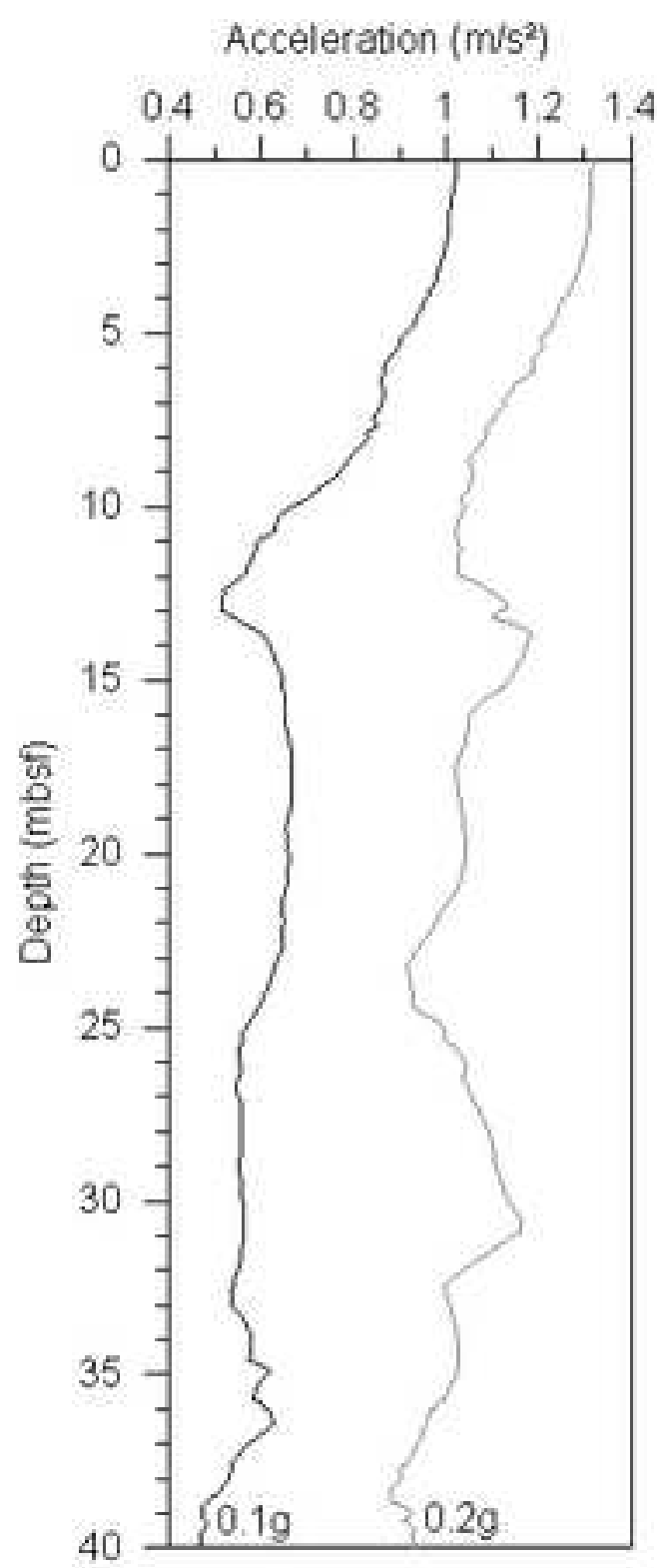

(a)

Excess pore pressure (KPa) Effective confinement (KPa)

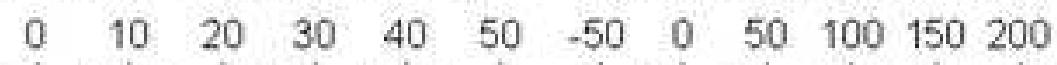

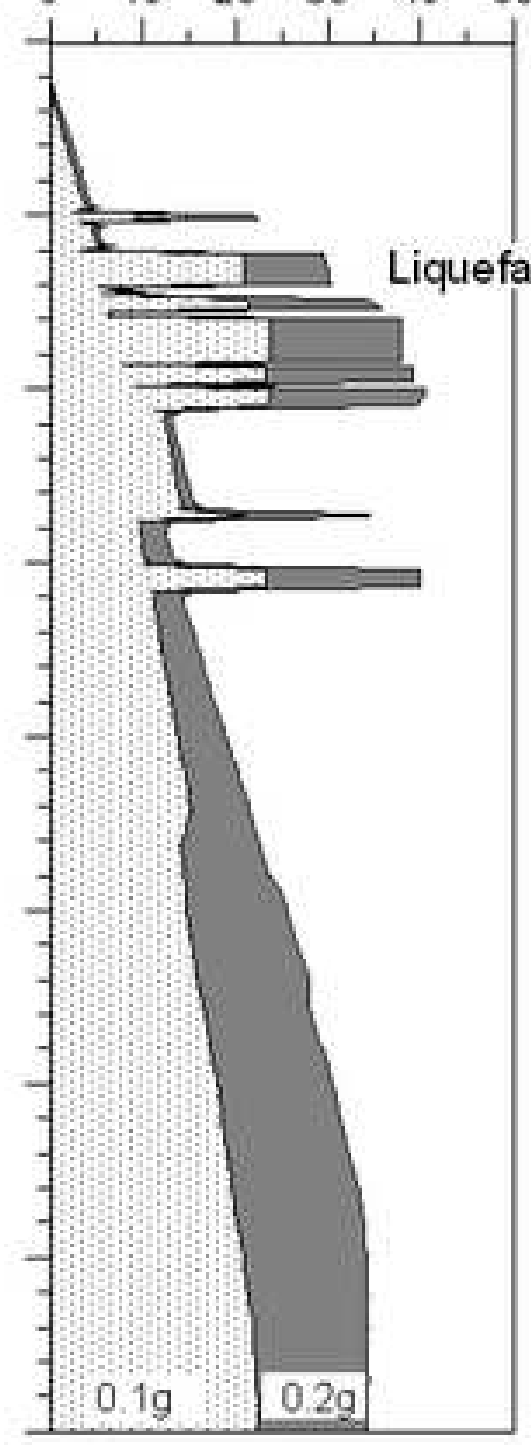

(b)

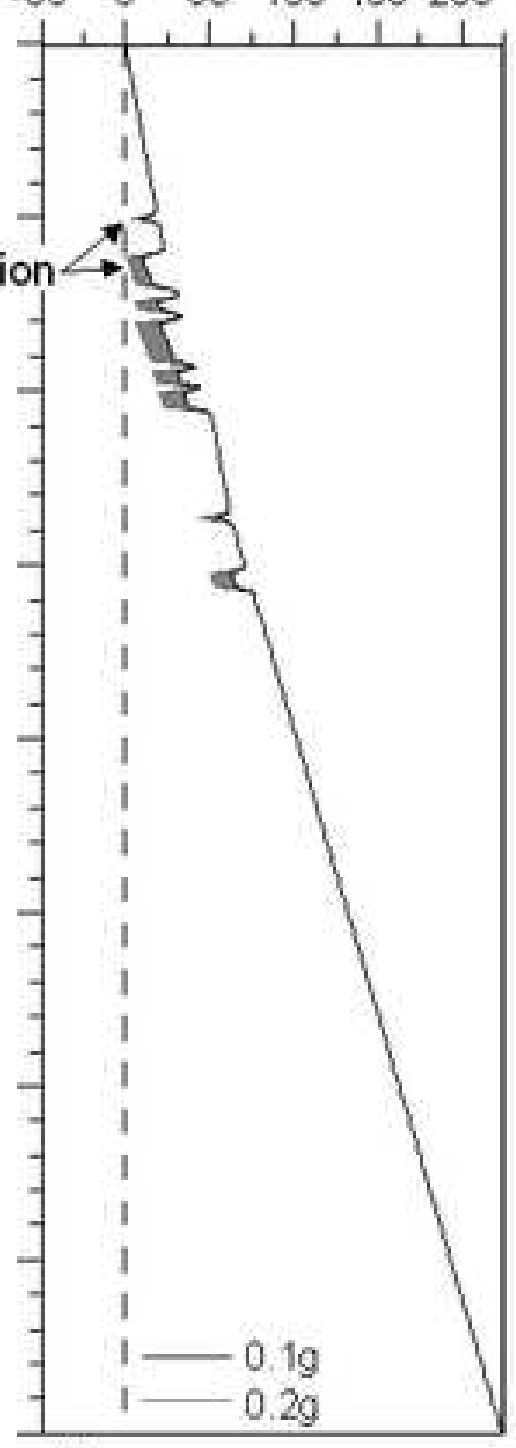

(c) 


\section{Figure14}

Click here to download high resolution image

(a)

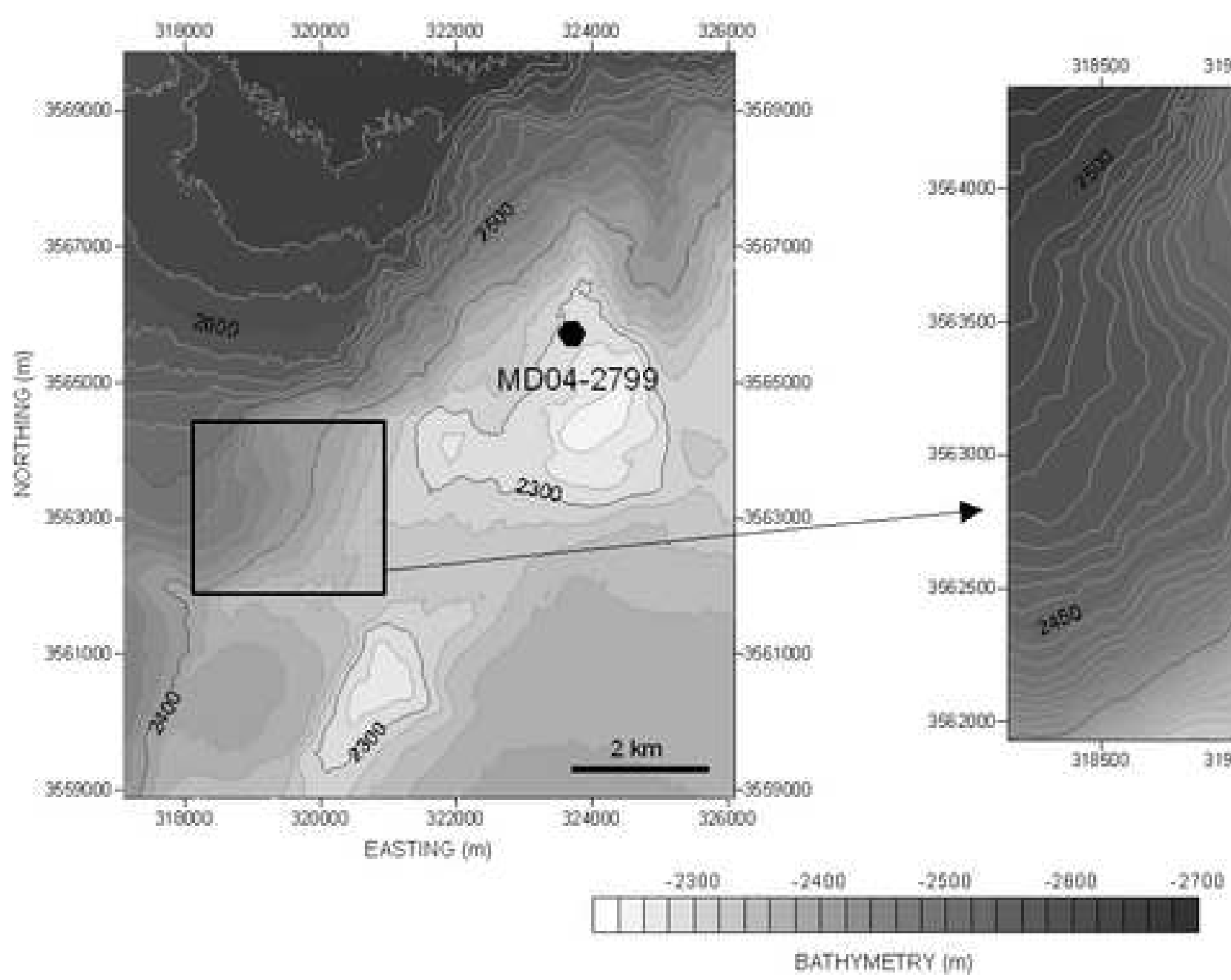

BATHYMETRY $(m)$

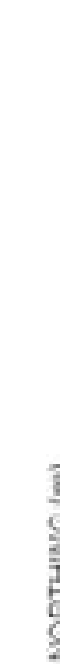

(b)

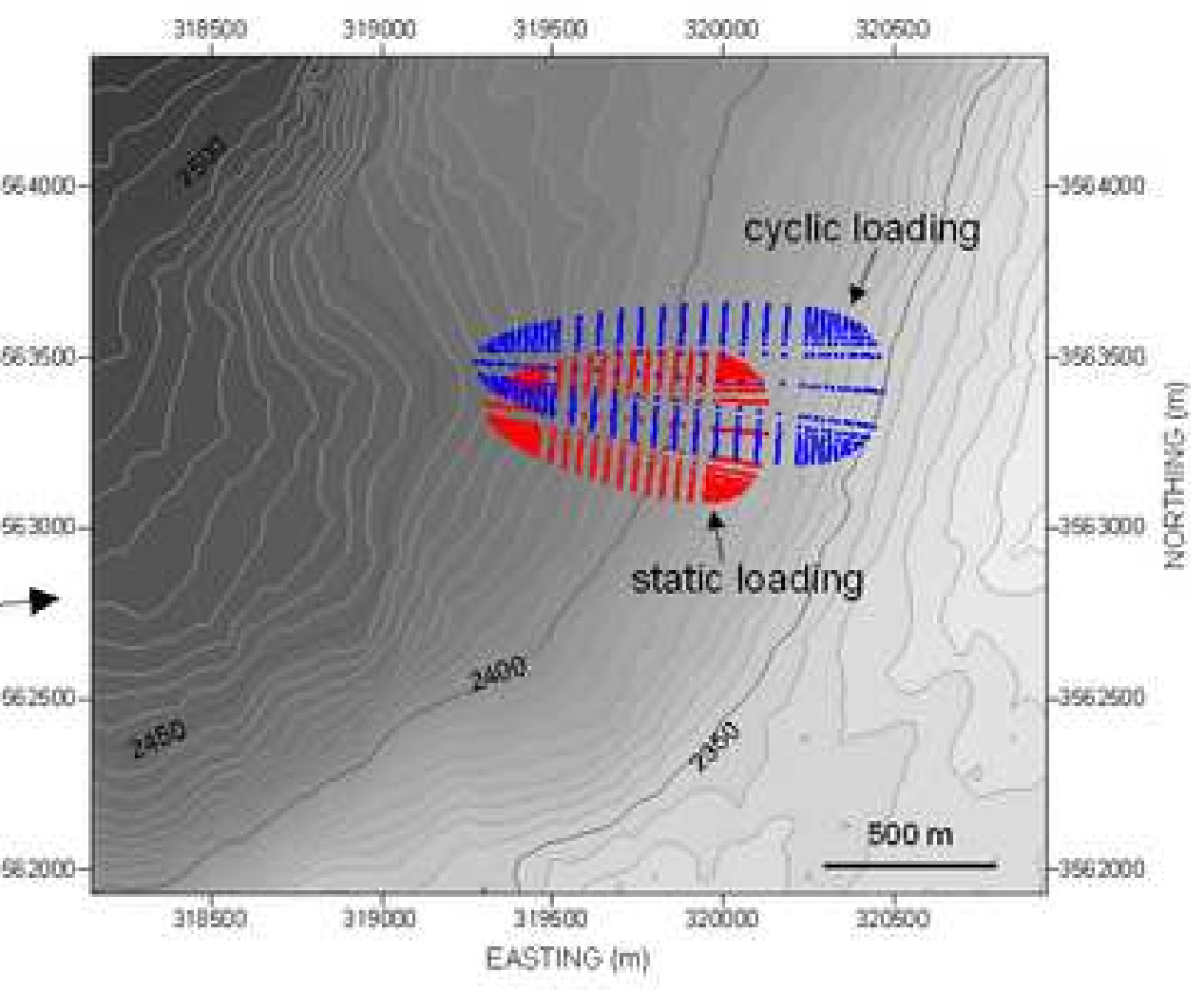

b)

E



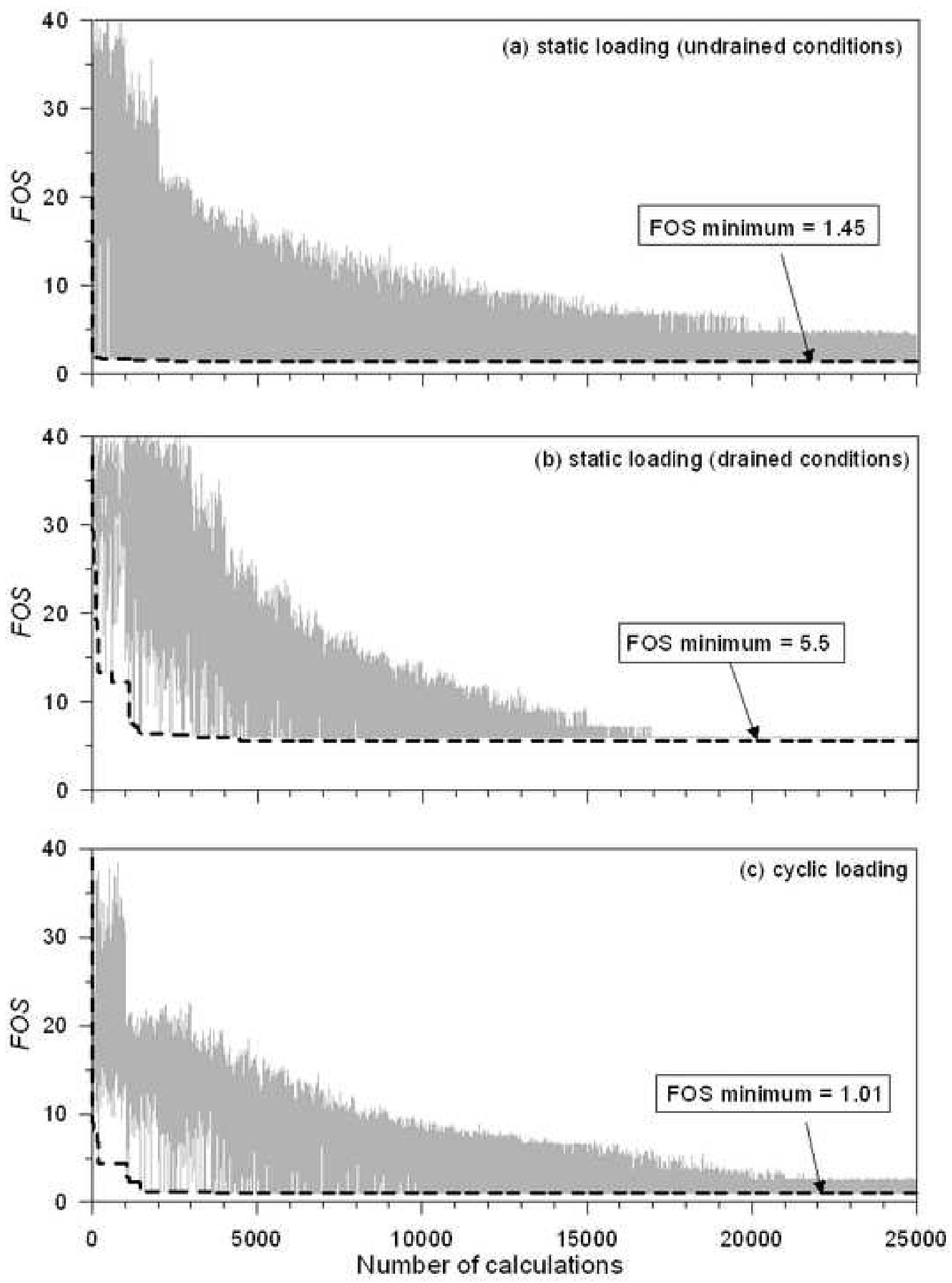

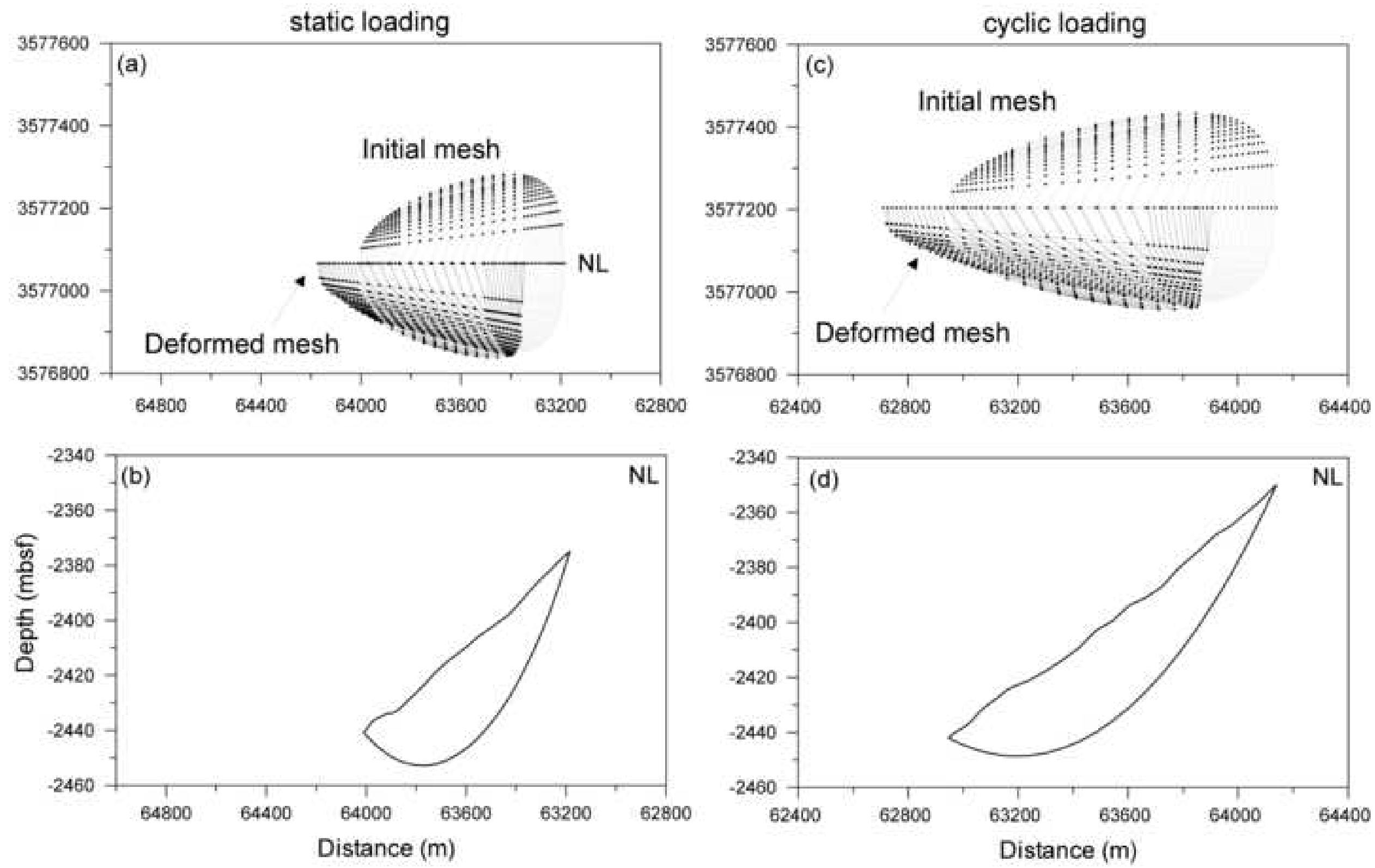


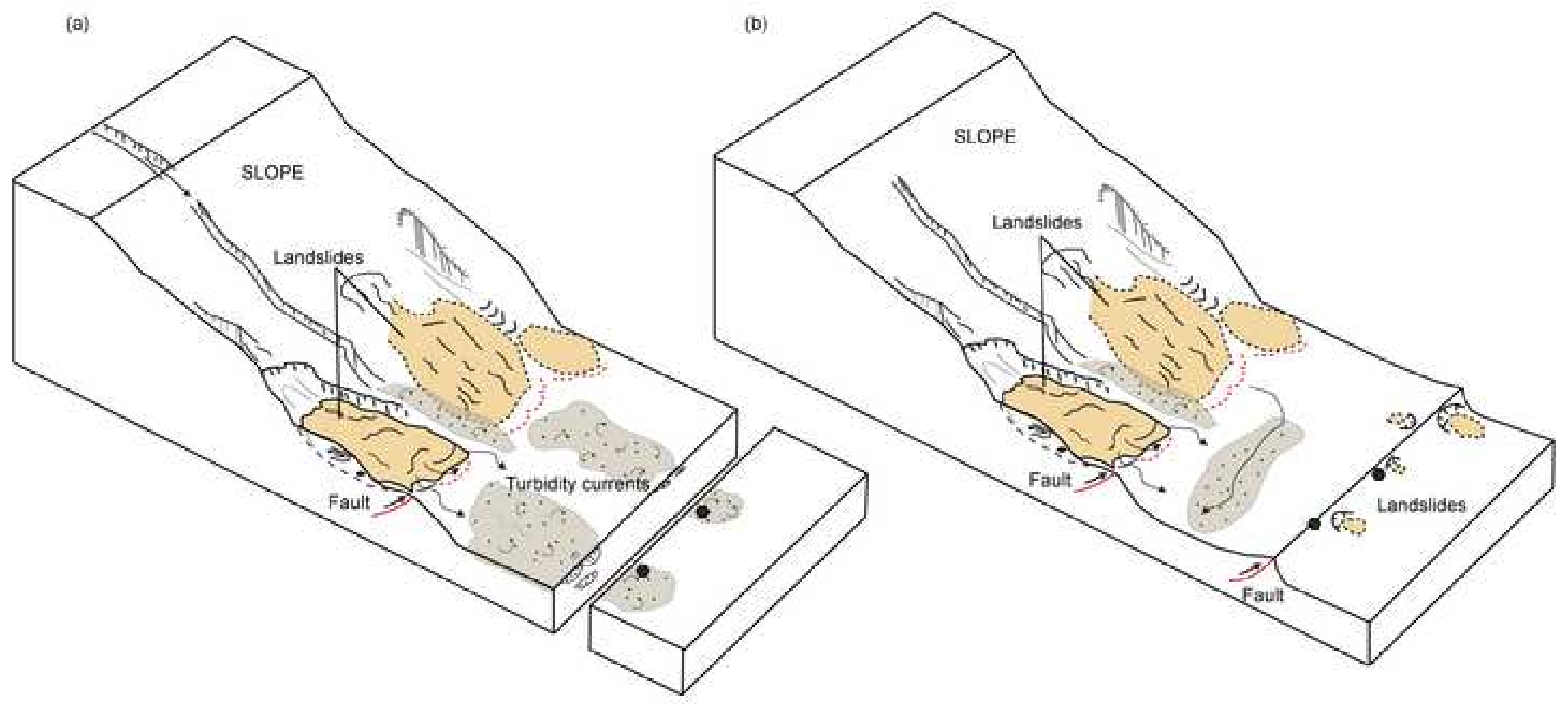




\begin{tabular}{|c|c|c|c|c|c|c|c|}
\hline Core & $\begin{array}{c}\text { Depth } \\
\text { (cm) }\end{array}$ & Material & $\begin{array}{c}{ }^{14} \mathrm{C} \\
\text { average } \\
\text { age } \\
\text { (BP) }\end{array}$ & $\begin{array}{c}\text { Analytical } \\
\text { error } \pm(B P)\end{array}$ & $\begin{array}{c}\text { Calibration } \\
\text { (cal. BP) }\end{array}$ & $\begin{array}{c}\text { Data } \\
\text { calibration }\end{array}$ & $\begin{array}{c}\text { A verage } \\
\text { age } \\
\text { (cal. BP) }\end{array}$ \\
\hline M D04-2799 & $390-392$ & $\begin{array}{c}\text { Planktonic } \\
\text { foraminifera }\end{array}$ & 8420 & 50 & 8969-9098 & $\begin{array}{c}\text { Reimer et al. } \\
(2004)\end{array}$ & 9033 \\
\hline KMDJ 16 & $20-22$ & $\begin{array}{c}\text { Planktonic } \\
\text { foraminifera }\end{array}$ & 1255 & 30 & $746-846$ & $\begin{array}{l}\text { Reimer et al. } \\
(2004)\end{array}$ & 796 \\
\hline KMDJ 16 & $420-422$ & $\begin{array}{c}\text { Planktonic } \\
\text { foraminifera }\end{array}$ & 12260 & 60 & $13661-13788$ & $\begin{array}{l}\text { Reimer et al. } \\
(2004)\end{array}$ & 13724 \\
\hline
\end{tabular}

\section{TABLE 1}




\begin{tabular}{|c|c|c|c|c|}
\hline Core & Depth $\mathbf{( m )}$ & $\begin{array}{c}\text { Preconsolidation } \\
\text { pressure } \\
\mathbf{( k P a )}\end{array}$ & $\begin{array}{c}\text { Vertical } \\
\text { effective } \\
\text { stress (kPa) }\end{array}$ & OCR \\
\hline MD 04-2799 & 2.45 & 13.9 & 13.9 & 1 \\
\hline M 04-2799 & 3.95 & 22.42 & 22.7 & 0.98 \\
\hline M 04-2799 & 7.42 & 45.15 & 44.66 & 1.01 \\
\hline M 04-2799 & 12.18 & 45.01 & 79.74 & 0.56 \\
\hline MD04-2799 & 14.57 & 59.15 & 96.7 & 0.61 \\
\hline MD04-2799 & 18.42 & 65.86 & 126.21 & 0.52 \\
\hline MD04-2799 & 23.60 & 90.73 & 165.47 & 0.55 \\
\hline K M DJ 16 & 0.83 & 15.85 & 5.58 & 2.84 \\
\hline KM DJ 16 & 1.85 & 18.30 & 18.85 & 0.97 \\
\hline KM DJ 16 & 2.85 & 20.32 & 35.47 & 0.57 \\
\hline
\end{tabular}

TABLE 2 


\begin{tabular}{|c|c|c|c|c|}
\hline Test & Subsection & Depth $(\mathbf{m})$ & $\boldsymbol{\sigma}_{{ }_{3 \mathbf{c}}}(\mathbf{k P a})$ & $\Delta \mathbf{q} / \boldsymbol{\sigma}^{\prime}{ }_{\mathbf{~} \mathbf{c}}$ \\
\hline 1 & $\mathrm{~V}-1$ & $6.96-7.06$ & 50 & 0.10 \\
\hline 2 & $\mathrm{~V}-2$ & $7.06-7.16$ & 50 & 0.40 \\
\hline 3 & $\mathrm{~V}-3$ & $7.16-7.26$ & 50 & 0.60 \\
\hline 4 & $\mathrm{VI}-1$ & $8.47-8.62$ & 50 & 0.70 \\
\hline 5 & $\mathrm{VI}-2$ & $8.62-8.77$ & 50 & 0.81 \\
\hline 6 & $\mathrm{VIII}-1$ & $11.50-11.65$ & 100 & 0.50 \\
\hline 7 & $\mathrm{VIII-2}$ & $11.65-11.8$ & 100 & 0.60 \\
\hline 8 & $\mathrm{IX}-1$ & $12.20-12.35$ & 100 & 0.70 \\
\hline 9 & $\mathrm{IX}-2$ & $12.35-12.5$ & 100 & 0.80 \\
\hline 10 & $\mathrm{XII}-1$ & $16.10-16.25$ & 100 & 0.40 \\
\hline 11 & $\mathrm{XII}-2$ & $16.25-16.40$ & 100 & 0.50 \\
\hline 12 & $\mathrm{XII}-3$ & $16.40-16.55$ & 100 & 0.60 \\
\hline
\end{tabular}

\section{TABLE 3}




\begin{tabular}{|c|c|c|c|c|c|c|c|c|}
\hline Layer & $\begin{array}{c}\text { Thickness } \\
\text { (m) }\end{array}$ & $\begin{array}{l}\text { Depth } \\
\text { (mbsf) }\end{array}$ & Lithology & $\begin{array}{c}\gamma \\
\left(k N / m^{3}\right)\end{array}$ & $\begin{array}{c}\mathrm{Su} \\
(\mathrm{kPa})\end{array}$ & $\begin{array}{c}\varphi^{\prime} \\
\text { (degrees) }\end{array}$ & \begin{tabular}{|c} 
Permeability \\
$(\mathrm{m} / \mathrm{s})$
\end{tabular} & $\begin{array}{c}\text { Vs } \\
(\mathrm{m} / \mathrm{s})\end{array}$ \\
\hline 1 & 5 & 5 & Silty clay & 15.50 & 4.78 & - & $5.5 \times 10^{-9}$ & $200 *$ \\
\hline 2 & 0.1 & 5.1 & Silt & 15.90 & - & 27 & $10^{-1 *}$ & $185^{*}$ \\
\hline 3 & 1 & 6.1 & Silty clay & 16.50 & 5.70 & - & $6 \times 10^{-9}$ & $200 *$ \\
\hline 4 & 0.9 & 7 & Sand & 17.79 & - & 31.5 & $6.6 \times 10^{-5 *}$ & $205^{*}$ \\
\hline 5 & 0.5 & 7.5 & Silty clay & 17.53 & 8.05 & - & $7.98 \times 10^{-9}$ & 190 \\
\hline 6 & 0.2 & 7.7 & Silt & 18 & - & 33 & $10^{-1 *}$ & $185^{*}$ \\
\hline 7 & 0.3 & 8 & Silty clay & 15.74 & 7.70 & - & $7.98 \times 10^{-9}$ & 150 \\
\hline 8 & 1.2 & 9.2 & Sand & 16.94 & - & 33 & $6.6 \times 10^{-5} *$ & $205^{*}$ \\
\hline 9 & 0.2 & 9.4 & Silty clay & 17.11 & 10.15 & - & $6.5 \times 10^{-9}$ & $200 *$ \\
\hline 10 & 0.4 & 9.8 & Sand & 17.79 & - & 33 & $6.6 \times 10^{-5 *}$ & $205^{*}$ \\
\hline 11 & 0.2 & 10 & Silty clay & 17.53 & 10.48 & - & $5.5 \times 10^{-9}$ & 232 \\
\hline 12 & 0.2 & 10.2 & Sand & 18 & - & 33 & $6.6 \times 10^{-5 *}$ & $205^{*}$ \\
\hline 13 & 0.3 & 10.5 & Silt & 16.94 & - & 33 & $10^{-1} *$ & $185^{*}$ \\
\hline 14 & 3.1 & 13.6 & Silty clay & 17.11 & 12.65 & - & $5.13 \times 10^{-9}$ & $200 *$ \\
\hline 15 & 0.1 & 13.7 & Sand & 17.79 & - & 35 & $6.6 \times 10^{-5} *$ & $205^{*}$ \\
\hline 16 & 1.5 & 15.2 & Silty clay & 17.53 & 14.34 & - & $4.21 \times 10^{-9}$ & 244 \\
\hline 17 & 0.5 & 15.7 & Sand & 18.03 & 6 & 35 & $6.6 \times 10^{-5} *$ & $205^{*}$ \\
\hline 18 & 24.3 & 40 & Silty clay & 18.50 & 27.45 & - & $1.61 \times 10^{-9}$ & $300 *$ \\
\hline
\end{tabular}

\section{TABLE 4}




\begin{tabular}{|c|c|c|c|c|c|c|c|}
\hline L ayer & $\begin{array}{c}\text { Thickness } \\
(\mathbf{m})\end{array}$ & $\begin{array}{c}\text { Depth } \\
(\mathbf{m b s f})\end{array}$ & L ithology & $\begin{array}{c}\boldsymbol{\gamma} \\
\left(\mathbf{k N} / \mathbf{m}^{\mathbf{3}}\right)\end{array}$ & $\begin{array}{c}\text { Su } \\
(\mathbf{k P a})\end{array}$ & $\begin{array}{c}\boldsymbol{\varphi}^{\prime} \\
(\mathbf{d e g r e e s})\end{array}$ & $\begin{array}{c}\text { Horizontal } \\
\text { acceleration } \mathbf{( g )}\end{array}$ \\
\hline 1 & 5 & 5 & Silty clay & 15.50 & 4.78 & $25^{*}$ & 0.099 \\
\hline 2 & 0.1 & 5.1 & Silt & 15.90 & - & 27 & 0.093 \\
\hline 3 & 1 & 6.1 & Silty clay & 16.50 & 5.7 & $25^{*}$ & 0.089 \\
\hline 4 & 1.6 & 7.7 & Sand & 17.00 & - & 33 & 0.087 \\
\hline 5 & 0.3 & 8 & Silty clay & 17.30 & 7.5 & $25^{*}$ & 0.085 \\
\hline 6 & 2.5 & 10.5 & Sand & 17.35 & - & 33 & 0.075 \\
\hline 7 & 4.7 & 15.2 & Silty clay & 17.40 & 12.9 & $25^{*}$ & 0.060 \\
\hline 8 & 0.5 & 15.7 & Sand & 18.03 & - & 35 & 0.066 \\
\hline 9 & 24.3 & 40 & Silty clay & 18.50 & 27 & $25^{*}$ & 0.060 \\
\hline
\end{tabular}

TABLE 5 